Article

\title{
Sustainability Prediction Model for Capital City Relocation in Indonesia Based on Inclusive Wealth and System Dynamics
}

\author{
Takuya Shimamura ${ }^{1}$ and Takeshi Mizunoya ${ }^{2, *(1)}$ \\ 1 Department of Urban and Environmental Engineering, Graduate School of Engineering, Kyushu University, \\ 744 Motooka, Nishi-ku, Fukuoka 819-0395, Japan; t.shimamura0818@gmail.com \\ 2 Faculty of Life and Environmental Sciences, University of Tsukuba, Tennodai, Tsukuba, \\ Ibaraki 305-8572, Japan \\ * Correspondence: mizunoya.takeshi.ff@u.tsukuba.ac.jp; Tel.: +81-29-853-7221
}

Received: 13 April 2020; Accepted: 21 May 2020; Published: 25 May 2020

\begin{abstract}
Based on inclusive wealth (IW), this paper evaluates the impact and sustainability of the Indonesian government's decision to relocate the capital city from Jakarta to East Kalimantan in terms of economic, human, and environmental aspects. This paper develops an integrated prediction simulation model based on IW and system dynamics and sets three scenarios, depending on the expected population recovery in Jakarta and the increased immigration into the new capital city (NCC) from the nearby areas after the public sector relocates. The most reliable scenario projects benefit of USD 169 billion in IW in 2050, equivalent to $2.41 \%$ of the expected cumulative real gross domestic product (GDP) growth in Indonesia from 2021 to 2050. Regarding the sustainability of the relocation, the current investment plans are not sustainable, largely because of the negative impact on human capital, comprising the education and health capital caused by the income gap between Jakarta and the NCC, and due to depreciation of produced capital. This study makes a significant contribution to the integrated evaluation of capital city relocations for Indonesia and beyond, because no previous study of such relocations combines produced, human, and natural capital. This is the first policy evaluation to include the impact of migration on IW, which plays an important role in IW literature, because population is a key model factor.
\end{abstract}

Keywords: inclusive wealth; system dynamics; sustainability prediction model; capital city relocation; Indonesia

\section{Introduction}

The Indonesian government declared that it would relocate the nation's capital city from Jakarta to East Kalimantan on August 16, 2019 [1]; however, only the government and the administrative sector would be relocated, keeping Jakarta as the economic center of Indonesia [2]. There are five reasons why this relocation should be beneficial for Jakarta, namely, (1) it will ease the heavy traffic congestion; (2) it will help slow down environmental degradation such as air and water pollution, (3) it will help make Jakarta less vulnerable to natural disaster risks such as earthquakes and/or tsunamis, volcanos, and floods; (4) it will mitigate the levels of economic and population concentration; and (5) it will relieve land subsidence caused by the pumping of groundwater [3,4]. The as-yet-unnamed new capital city (NCC) in East Kalimantan, unlike Jakarta, is located in the geographical center of Indonesia, which is expected to enhance the national motto Bhinneka Tunggal Ika, or unity in diversity, with its 300 ethnic groups; it would also reduce the likelihood of severe impacts from natural disasters compared to most areas in Indonesia [5]. 
Kalimantan (Borneo) Island, however, has one of the oldest and largest tropical rainforests in the world, which has faced rapid deforestation since 2000, leading to a decline in native species such as the orangutan and the proboscis monkey [6,7]. Some environmental NGOs warn that the capital city relocation will accelerate environmental degradation in East Kalimantan [8]. A comprehensive evaluation of the impacts of relocation is needed in both Jakarta and the NCC. To develop such an evaluation model, this paper applies inclusive wealth (IW) as an evaluation criterion and system dynamics (SD) as a simulation model. To the best of our knowledge, the only study to have employed the combination of IW and SD is an evaluation of energy policies in Belgium and Egypt [9]. Several studies evaluate other policies using IW [10,11]; however, none assesses capital city relocation or includes the evaluation of migration affecting human capital (HC) and land conversion damaging natural capital (NC). Furthermore, no integrated study projecting the impact of relocation in Indonesia has been conducted.

IW was developed by the United Nations University's International-Human Dimensions Programme (UNU-IHDP) on Global Environmental Change and the United Nations Environmental Programme (UNEP) as an index to measure long-term well-being and sustainability [12]. The first Inclusive Wealth Report (IWR) was published in 2012 [13], and followingly in 2014 [14] and in 2018 [15]. The features of IW are (1) an inclusive or integrated index to evaluate wealth in terms of produced capital (PC), HC, and NC; (2) an index to internalize the evaluation of sustainability by measuring stock rather than flow; (3) an index to analyze the trade-off effects among capitals assets; and (4) an index to show the required amount of investment to sustain capital stocks [13-15]. PC comprises equipment, machineries, roads, and others; HC comprises education and health capitals; NC consists of fossil fuels, minerals, agricultural land, and forest resources [14,15]. The IWRs have revealed a trade-off effect between PC and NC and shown that IW per capita growth and gross domestic product (GDP) per capita growth are not always parallel; furthermore, the improvement of IW growth contributes to increased GDP growth [13-15].

SD is "a method to enhance learning in complex systems" [16], whose central concept is to evaluate the interactions among all variables in a system [17]. Cost-benefit analysis (CBA) is also a common method for the assessment of public projects. However, CBA is lacking a dynamic view because it does not take interactions between components into account; thus, SD is more suitable to simulate interdisciplinary dynamics [18]. Combining SD with IW, it becomes possible to evaluate the integrated dynamics of the relocation.

This paper has three objectives, namely, (1) to contribute to the development of an integrated prediction model of social policy related to urban planning using the IW, which will contribute to the literature on capital city relocations, where studies are still limited; (2) to evaluate the social impacts of capital city relocation in Indonesia from the viewpoint of each capital asset (PC, HC, and NC) of IW and other aspects, including changes in population and air pollutant emission levels in both Jakarta and the NCC, which contributes to the literature on integrated policy evaluation using IW; and (3) to assess the sustainability of the social well-being affected by capital city relocation in Indonesia, which contributes to the literature on sustainability evaluation of social policies.

\section{Materials and Methods}

\subsection{Framework of Study}

To fulfill an integrated dynamic evaluation combining IW and SD, the framework in this paper attempts to develop a model database by collecting broad-rage data sources (Figure 1). There are six main data sources. Population, nature, and emission data are taken from World Population Prospects 2019 (WPP) [19], the Food and Agriculture Organization (FAO) [20] and the Emission Database for Global Atmospheric Research (EDGAR) [21,22]. These data, including the approximation of discrete numbers by linear models, the calculation of cropland growth rates, and the estimation of emission factors, were analyzed using R software. Accessing local institutions in Indonesia such as Statistics 
Indonesia [23] and the Ministry of National Development Planning of Indonesia (BAPPENA) [3,4] this study collected specific information of the relocation plan, local regulations, public sector, and so on. Labor and disaster risk data were provided by the International Labour Organization (ILO) [24] and the Lloyd's Disaster Risk Index (LDRI) [25].

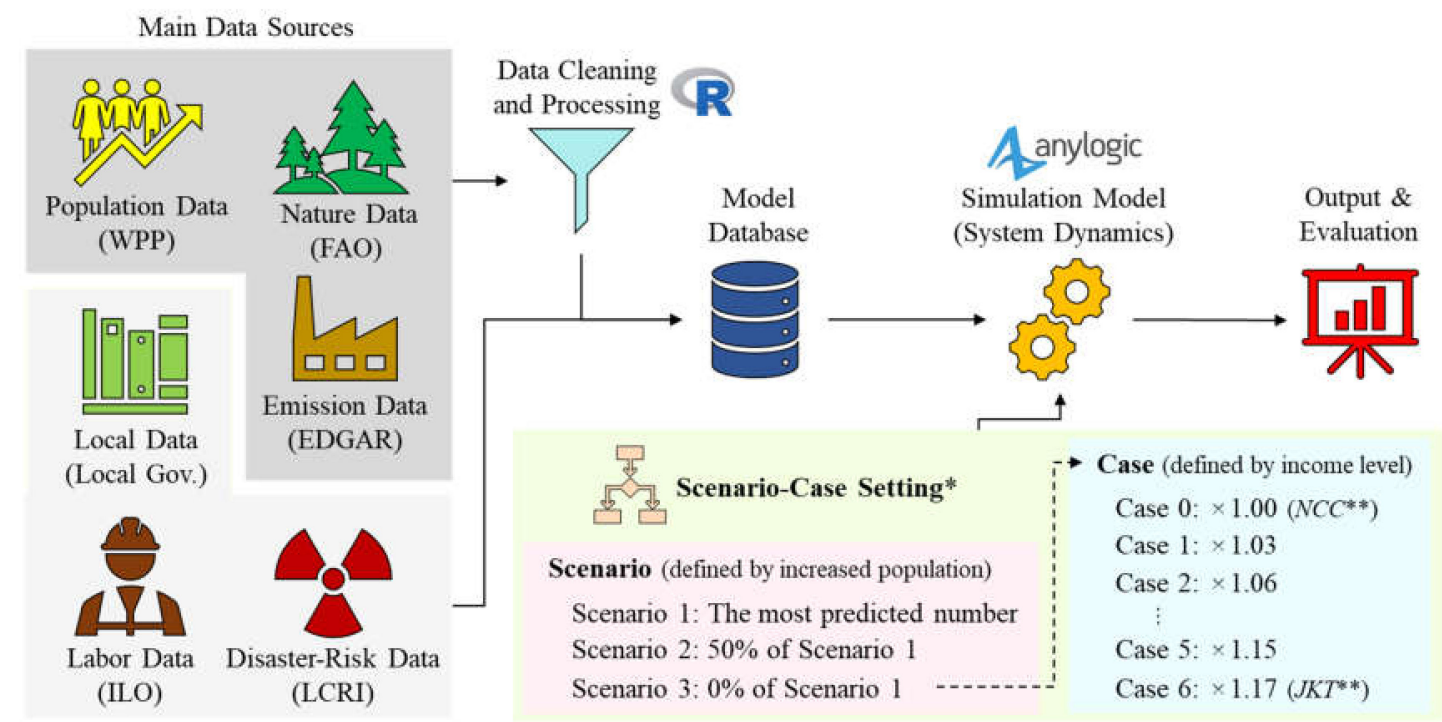

Figure 1. Study framework. * Scenario depends on increased population both in Jakarta and the new capital city (NCC). Case is considered only in Scenario 3, relying on income level in the NCC. ${ }^{* *} J K T$ and NCC are current minimum wages in Jakarta and the NCC.

Relying on the model database, the simulation model based on SD calculates three scenarios, where Scenario 3 has seven cases (see Section 2.4), via the AnyLogic software. The output reveals the change in capital stocks defined by IW and other variables such as population and resilience against natural disasters.

\subsection{Capital City Relocation in the Context of Indonesia}

There are several previous examples of capital relocation of administrative centers: Australia, Brazil, Nigeria, Malaysia, and Myanmar [5,26-28]. This paper sets seven criteria that impact population growth in both the former and the new capital city in order to select cases similar to Indonesia's, including: (1) objectives of the relocation, (2) transferred functions, (3) condition of the former capital city after the relocation, (4) geographical location of the new capital city, (5) distance between the former and the new capital city, (6) size of expenditure for relocation, and (7) type of government at time of relocation. Based on these criteria, the relocation in Brazil can be considered the most similar case to Indonesia $[26,29,30]$. For example, Brazil matches Indonesia on the first four criteria. The distances between the former and new capital city are large- $900 \mathrm{~km}$ in Brazil and $1250 \mathrm{~km}$ in Indonesia. In addition, Brazil spent 2-3\% of annual GDP [29] on relocation, similar to the $3.27 \%$ expended by Indonesia [3,4].

Figure 2 shows the urban plan and time schedule of NCC development in Indonesia [4]. Indonesia aims to build a core area of 2000 ha for the presidential palace and the three branches-judicial, administrative, and legislative-by 2024. It plans to begin using the NCC as the capital city as soon as possible. The majority of functions and facilities will be developed by 2029 and contained within 40,000 ha, which is smaller than the current capital city, Jakarta, whose area is 66,162 ha [31]. The metropolitan area of the NCC will be expanded by around 200,000 ha, which will include a national park and orangutan conservation center. 


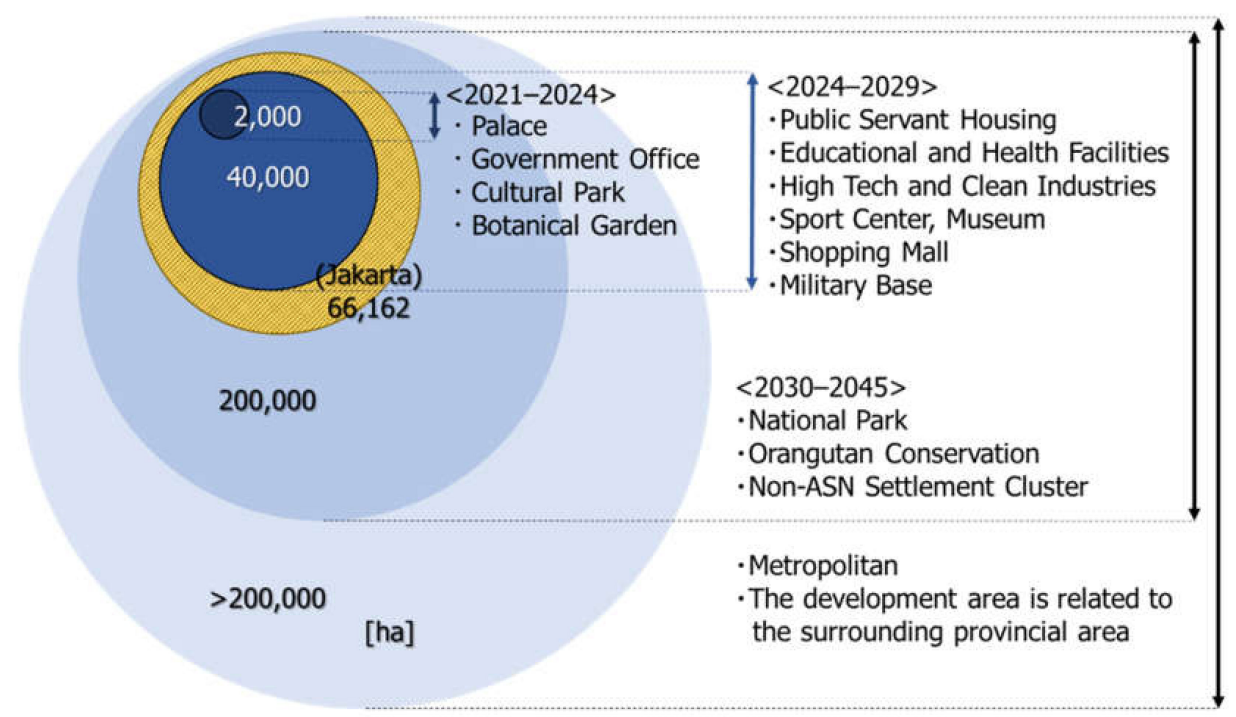

Figure 2. The urban plan and time schedule of the new capital city in Indonesia. Source: [4].

Table 1 shows the estimated expenditures and budgeted resources for the capital city relocation project in Indonesia. Around $20 \%$ of the cost is subsidized by the government; about one fifth is invested by the private sector; and more than half is covered by a public-private partnerships (PPP) scheme $[3,4]$.

Table 1. Expenditures and sources of financing for the capital city relocation.

\begin{tabular}{|c|c|c|c|c|c|c|}
\hline \multirow{2}{*}{ No. } & \multirow{2}{*}{ Component } & \multicolumn{2}{|c|}{ Expenditures } & \multicolumn{3}{|c|}{ Sources of Financing } \\
\hline & & USD (Billion) & Ratio (\%) & Government & PPP $^{1}$ & Private \\
\hline \multirow{5}{*}{1} & Main Functions: & \multirow{5}{*}{3.73} & \multirow{5}{*}{11.0} & \multirow{4}{*}{-} & - & \multirow[t]{5}{*}{-} \\
\hline & 1. Legislative building & & & & V & \\
\hline & 2. Executive building & & & & $\mathrm{V}$ & \\
\hline & 3. Judiciary building & & & & $\mathrm{V}$ & \\
\hline & $\begin{array}{l}\text { 4. State Palace and strategic buildings of the } \\
\qquad \text { TNI }^{2} / \text { POLRI }^{3}\end{array}$ & & & $\mathrm{~V}$ & & \\
\hline \multirow{6}{*}{2} & Supporting Functions: & \multirow{6}{*}{17.08} & \multirow{6}{*}{50.2} & - & - & - \\
\hline & 1. Official residence (terraced, $\mathrm{ASN}^{4}$ \& & & & V & $\mathrm{V}$ & $\mathrm{V}$ \\
\hline & $\begin{array}{l}\text { 2. Educational facilities (elementary, middle, } \\
\text { high school) }\end{array}$ & & & & V & $\mathrm{V}$ \\
\hline & 3. Educational facilities (higher education) & & & & $\mathrm{V}$ & $\mathrm{V}$ \\
\hline & 4. Health facilities & & & & $\mathrm{V}$ & \\
\hline & 5. Penitentiary & & & & V & \\
\hline \multirow{3}{*}{3} & Supporting Functions: & \multirow{2}{*}{12.36} & \multirow{2}{*}{36.3} & \multirow[t]{2}{*}{-} & - & - \\
\hline & $\begin{array}{l}\text { 1. Facilities and infrastructure (roads, electricity, } \\
\text { telecommunications, drinking water, drainage) }\end{array}$ & & & & $\mathrm{V}$ & \\
\hline & 2. Green open space & 0.29 & 0.9 & $\mathrm{~V}$ & & \\
\hline 4 & Land Procurement Needs & 0.58 & 1.7 & $\mathrm{~V}$ & & \\
\hline & Total & 34.05 & 100 & - & - & - \\
\hline
\end{tabular}

Note: ${ }^{1}$ Public-Private Partnerships. ${ }^{2}$ Indonesian National Armed Forces. ${ }^{3}$ Indonesian National Police. ${ }^{4}$ Public Servant. Sources: $[3,4]$.

\subsection{Study Area}

The two study areas for this research include the current capital city Jakarta (JKT) and the new capital city (NCC) in East Kalimantan (Figure 3). Jakarta has a total area of $661.5 \mathrm{~km}^{2}$ and a population of 9.6 million people [23]. To correctly identify the study area of the NCC, this paper conducted an on-site inspection in East Kalimantan on January 2020; North Penajam Paser and Balikpapan were selected as the study areas, with a total area of $3759 \mathrm{~km}^{2}$ and a population of 0.14 million people [23]. 


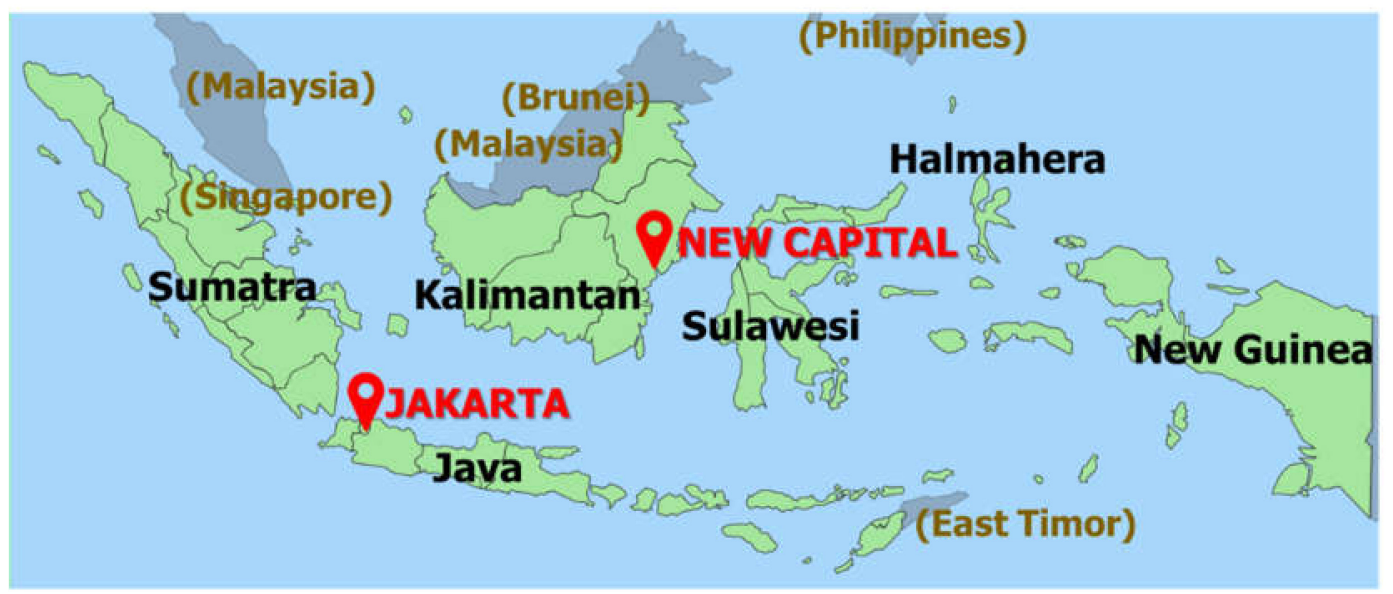

Figure 3. Locations of Jakarta and the new capital city.

This paper considers two study areas, namely, Jakarta and the NCC, as the concerned system analyzed in this paper. The relocation will trigger migration not only from Jakarta to the NCC, but also from outside to inside the concerned system. This paper defines migration from outside the system to Jakarta as population recovery in Jakarta, and from outside to the NCC as increased immigration into the NCC (Figure 4).

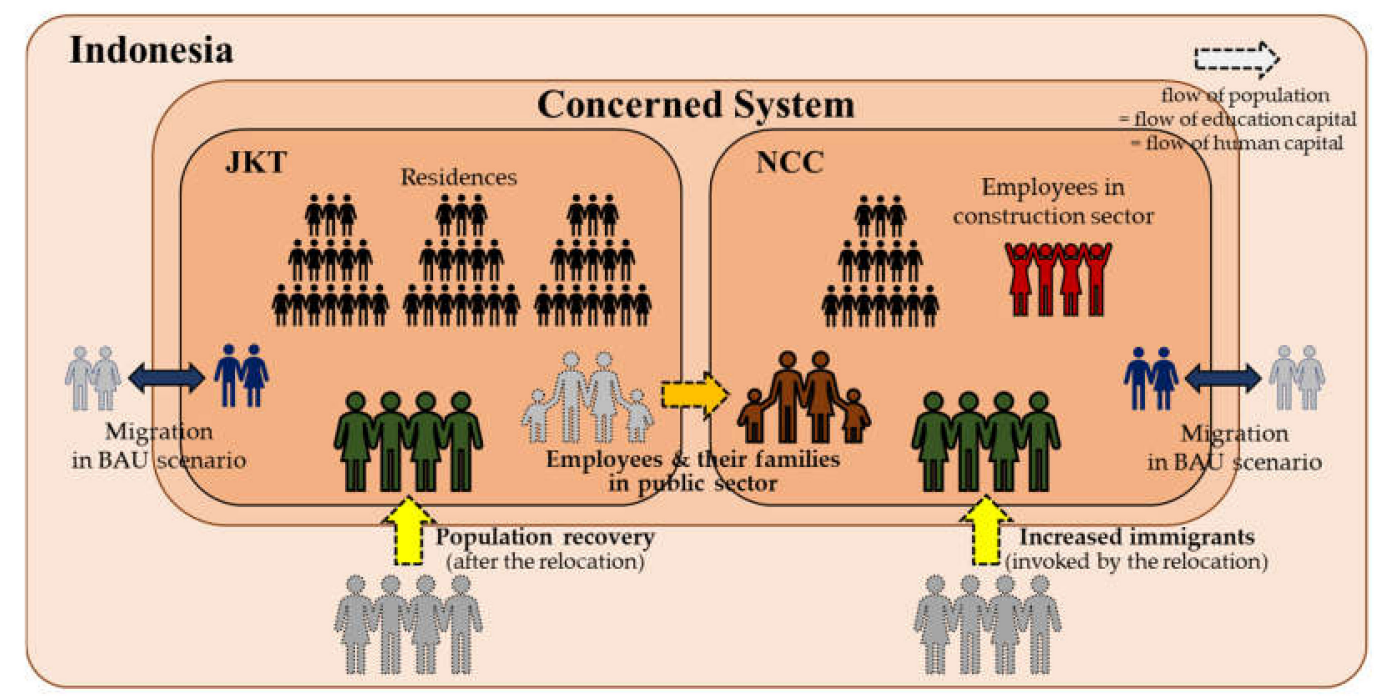

Figure 4. Flow of migration caused by the capital city relocation.

Relocation also has an impact outside the system through emigration, because population influences regional IW directly and indirectly. Therefore, for the sustainability evaluation of well-being affected by the relocation project itself, the impact of migration from outside the concerned system, such as that of population recovery in Jakarta and that of increased immigration into the NCC, should be excluded (which this paper does in Scenario 3, one of the scenarios explained in detail in the next section).

\subsection{Three Scenarios Depending on Population Recovery and Increased Migrants}

This paper develops three scenarios depending on two factors, namely, (1) population recovery rate in Jakarta and (2) increased immigration rate into the NCC (Table 2). Scenario 1 is the most likely one, estimated from the previous study in Brazil [26,32]. Scenario 2 has a middle value between Scenario 1 and Scenario 3, allowing the impacts of IW to be traced depending on the changes due to 
population recovery in Jakarta and increased immigration into the NCC. In other words, Scenario 2 has exactly half the immigrants from outside the concerned system as Scenario 1 . Then, as mentioned above, this paper proposes a scenario to evaluate the sustainability of the capital city replacement itself, which is Scenario 3. This is because migration internalizes the transfer of HC; for example, immigration from another place to Jakarta will decrease HC in the location the immigrants are leaving. Thus, only the sustainability of the relocation itself should be measured, excluding immigration from outside Jakarta and the NCC.

Table 2. The values of population recovery rate in Jakarta and increased immigration rate into the NCC for the three scenarios [\%].

\begin{tabular}{ccccc}
\hline & Jakarta & \multicolumn{3}{c}{ NCC } \\
\cline { 2 - 5 } & Population Recovery Rate & \multicolumn{3}{c}{ Increased Immigration Rate } \\
& $\mathbf{2 0 2 1 - 2 0 5 0}$ & $\mathbf{2 0 2 1 - 2 0 3 0}$ & $\mathbf{2 0 3 1 - 2 0 4 0}$ & $\mathbf{2 0 4 1 - 2 0 5 0}$ \\
\hline Scenario 1 & 90 & 9.93 & 4.78 & 0.75 \\
Scenario 2 & 45 & 4.97 & 2.39 & 0.38 \\
Scenario 3 & 0 & 0 & 0 & 0 \\
\hline
\end{tabular}

Note: Scenario 1 is estimated through [26,32]. Scenario 2 has half the value of Scenario 1.

This paper also considers seven cases in Scenario 3 to qualify the impact of income level on education capital, HC, and IW, depending on the adjusted income level in the NCC. The adjusted factor of income level in the NCC is defined by the following equation:

$$
\text { Adjusted income level }=\text { mean annual individual income in the NCC } \times \text { Adjusted factor }
$$

where Adjusted factors range from 1.00 to 1.15 in every 0.03 , and 1.17 is equivalent to the income level in Jakarta; that is, Case 0 is the same as the current income level in the NCC; Cases 1, 2, 3, 4, and 5 represent 1.03, 1.06, 1.09, 1.12, and 1.15 times higher income level, respectively; and Case 6 is 1.17 higher, the equivalent to the income in Jakarta.

\subsection{System Dynamics Model}

This paper develops an SD (causal loop) model to evaluate the impacts of capital city relocation on IW both in Jakarta and the NCC (Figure 5). This paper accounts for three capital assets, which comprise IW, namely, PC, HC, and NC, applying the same model for both Jakarta and the NCC. Some variables are assumed to be 0 ; for instance, construction, cropland, and forest in Jakarta, and productivity and extra land in the NCC. Using a 30-year simulation period, from 2021 to 2050, this paper traces the changes in the inclusive wealth index (IWI) at a time $t$ following Equation (1):

$$
\Delta I W I(t)=\Delta P C(t)+\Delta H C(t)+\Delta N C(t)
$$

Furthermore, considering the accumulative expected loss caused by natural disasters (ND), this paper evaluates IWI+ (IWIplus) through Equation (2):

$$
\Delta \operatorname{IWIplus}(t)=\Delta \operatorname{IWI}(t)-\Delta N D(t)
$$

This paper calculates the final values in 2018 USD, and converts IDR into USD using the exchange rate [33] and USD from previous years into 2018 USD, using the consumer price index (CPI) [34]. 


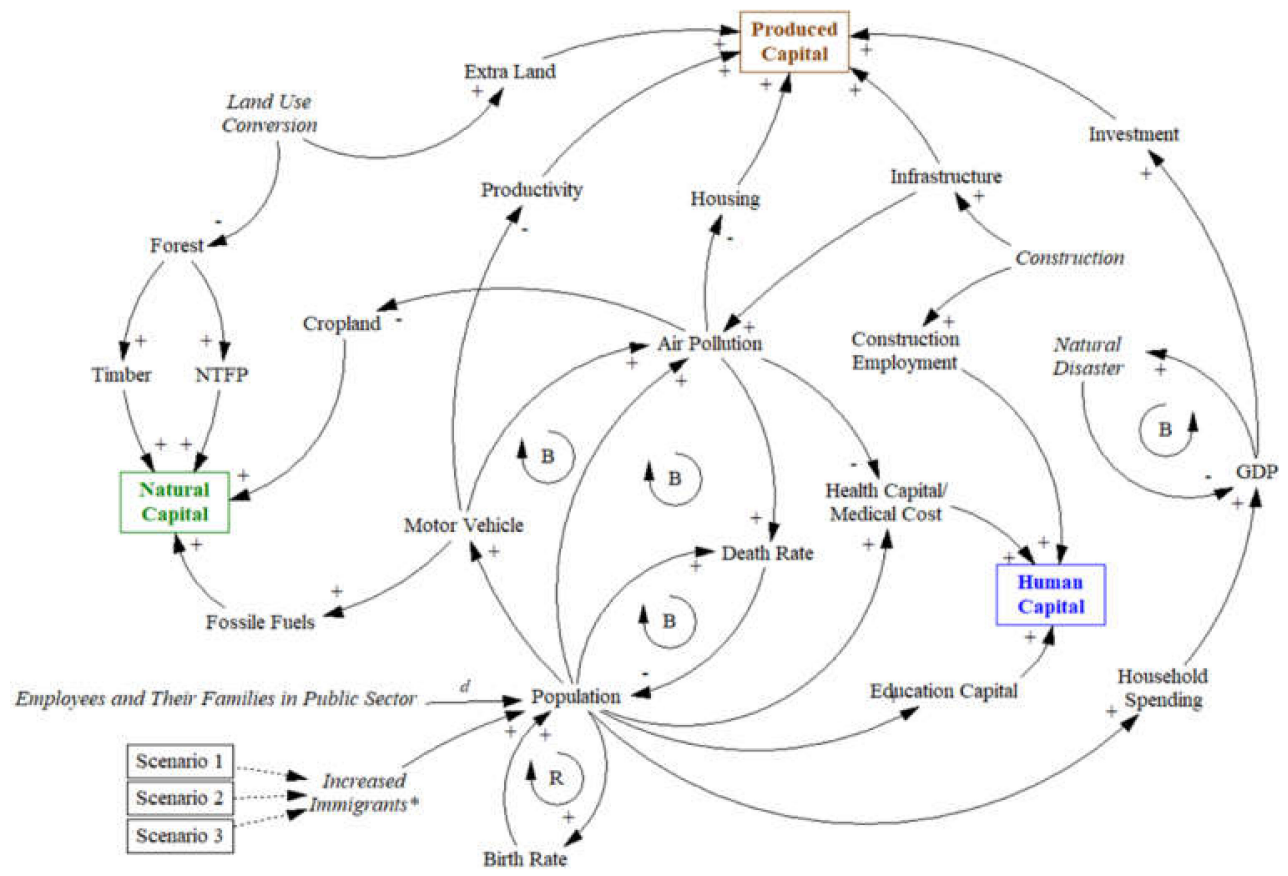

Figure 5. Causal loop diagram to evaluate the impacts on the Inclusive Wealth Index. Variables in italic indicate the direct impacts caused by the capital city relocation. For causal links (arrows), positive $(+)$ and negative (-) symbols refer to how the dependent variable is affected by the change in the independent variable. " $d$ " is "-" in Jakarta and "+" in the NCC because this link stands for migration from Jakarta to the NCC. The value of Increased Immigrants, from outside the concerned system, depends on the scenario. " $\mathrm{R}$ " and " $\mathrm{B}$ " are loop identifiers to show reinforcing (positive) and balancing (negative) loops, respectively.

\subsubsection{Model of Produced Capital}

To model PC, this paper accounts for five factors: infrastructure in the NCC, available land in Jakarta, housing in both cities, productivity in Jakarta, and investment flow in both cities. IWR 2014 [14] defines PC as comprising equipment, machineries, roads, and others; thus, infrastructure development in the NCC should be evaluated as the main factor of PC. Regarding the infrastructure in the NCC, this paper considers the land that will be available following the move of the administrative offices in Jakarta as estate capital assets. Housing is also an important form of estate capital. Yusuf and Resosudarmo [35] reveal the willingness-to-pay (WTP) for air pollution in Indonesia and, finding that some air pollutants have statistically significant impacts on housing prices. In other words, the quality of an estate asset is affected by the concentrations of some air pollutants, though the quantity of the estate does not change. Although the productivity is not defined as a factor of PC in IW, total factor productivity (TFP) is considered in the adjusted IW [14]. Moreover, inefficient productivity and economic losses caused by traffic congestion are one of the biggest urgent issues in Jakarta [36-38]; hence, this paper takes productivity as a factor of $\mathrm{HC}$ in Jakarta into consideration. On the other hand, a similar decline in productivity is not expected to happen in the NCC due to the well-designed urban plan and adequate transportation system. Therefore, productivity is accounted for only in Jakarta.

Following the same method as IWR 2012 [13], $\Delta \mathrm{PC}$ at time $t$ is qualified through Equation (3):

$$
\begin{gathered}
\Delta P C_{i}(t)=\sum_{\tau=1}^{t}\left\{\Delta I_{i}^{k}(t) \cdot\left(1-\delta^{P C}\right)^{t-\tau}\right\} \\
\Delta I_{i}^{k}(t)=\left\{\operatorname{NetInfra~}_{N C C}(t), \Delta \text { ExtLand }_{J K T}(t), \Delta \operatorname{Housing}_{i}(t), \Delta P_{J K T}(t), \Delta \operatorname{Inv}_{i}(t)\right\}
\end{gathered}
$$


where $\Delta I_{i}^{k}(t)$ is the change in investment of capital $k$ in place $i$ at time $t$ [USD], and $\Delta N e t I n f r a_{N C C}$ is the net invested infrastructure value in the NCC [USD]. This paper modifies the method of Aly and Managi [9] for the evaluation of stock value, subtracting operational and management costs [39], labor cost [40], and loan payback. For loan payback, this paper applies the capital recovery factor [9]. Next, $\triangle E x t \operatorname{Land}_{J K T}$ is the value of available land following the relocation of buildings to the NCC [USD] [41,42], and $\Delta$ Housing is the change in housing quality caused by air pollution [USD]. Following a previous study [35], this paper considers carbon oxide $(\mathrm{CO})$ and sulfur dioxide $\left(\mathrm{SO}_{2}\right)$ as causal air pollutants. $\Delta P$ is the change in total productivity [USD] related to Jakarta's serious traffic congestion, which may damage productivity in various ways, such as lost opportunity cost, increased fuel cost, and additional health problems caused by extra air pollution [36-38]. This paper computes the lost opportunity cost as productivity, under PC, increased fuel usage as the fossil fuel assets, under NC, and additional health problem as "health capital", under HC. Finally, $\delta^{P C}$ is the depreciation rate of PC, which is assumed to be $4 \%$ [43]. $\Delta I n v$ is the change in flow value of investment defined by GDP [USD]. An increased GDP generates greater investment, which makes PC larger [11]. In this paper, larger household spending, including government transfers [44] caused by immigration, generates greater GDP [45]; as a result, investment is increased.

\subsubsection{Model of Human Capital}

This paper evaluates four factors for HC, namely, education capital, health capital, medical cost, and temporary employment in construction. According to IWR 2012 [13], HC comprises education and health capital, where education capital is defined by the population, their educational attainment, their income, and the remaining duration of employment. Strictly speaking, temporary construction employees from outside the concerned system should not be considered when evaluating population growth with respect to Jakarta and the NCC. Therefore, this paper considers temporary construction employment not as existing education capital, but as demanded labor capital for the capital city relocation.

According to IWR 2018 [15], the state of one's health affects his/her human well-being through at least three channels: well-being (directly), rising productivity, and extending life years. However, well-being and rising productivity are difficult to evaluate, so the latter value is here computed as human capital. On the other hand, there is an established evaluation methodology to determine economic loss caused by air pollution in terms of mortality and productivity loss in flow value [46]. Combining both concepts, this paper evaluates the change in health capital stock impacted by concentrations of air pollutants in terms of the change in life years and human productivity. Furthermore, air pollution causes additional medical costs.

This paper defines the $\triangle \mathrm{HC}$ as shown in Equation (4):

$$
\Delta H C_{i}(t)=\left\{\begin{array}{lr}
\Delta E d u_{i}(t)+\Delta \operatorname{Health}_{i}(t)+\Delta \operatorname{MedCost}_{i}(t), & i=J K T \\
\Delta E d u_{i}(t)+\Delta \operatorname{Health}_{i}(t)+\Delta \operatorname{MedCost}_{i}(t)+\Delta \operatorname{Emp}_{i}(t), & i=\text { NCC }
\end{array}\right.
$$

where $\Delta E d u$ is the change in the stock value of education capital determined by the number of individuals in the population aged 15 years and above, along with their educational attainment and income levels [USD], following the same method as IRW 2012 [13] (pp. 281-282). We obtained educational attainment data from the United Nations Development Programme [47] and income data from the ILO [24] and classify both into three sectors, namely, public sector, construction sector, and others; additionally, the educational interest rate is assumed to be $8.5 \%$ [48], as is the HC depreciation rate [13]. $\Delta$ Health is the change in the stock value of health capital affected by air pollution [USD]. This paper uses the value of statistical life (VSL) for the economic value of mortality and the minimum income for the value of human productivity. $\Delta M e d C o s t$ is the medical cost caused by air pollution [USD]. In order to convert the medical cost calculated as flow value [46] into stock value, this paper assumes that the saved (increased) medical cost invokes (deprives) investment with a depreciation rate of $4 \%$, the same as that of PC. $\Delta E m p$ is the change in the stock value of employment 
[USD]. Although the equation is fundamentally the same as that of education capital, this paper assumes the value even during the 25 years of the employment period.

\subsubsection{Model of Natural Capital}

For NC, this paper evaluates four factors from the IWR 2014 [14], namely, fossil fuels, crop land, and timber and non-timber forest products (NTFP). Traffic congestion in Jakarta causes inefficient fuel usage [36]; thus, less congestion caused by migration from Jakarta to the NCC will save storage on fossil fuels. Air pollutants damage the crop yield [49], which impacts the quality of cropland. Following the same ExternE methodology [50], this paper evaluates the change in the quality of cropland caused by air pollutants. The decline in forest resources caused by deforestation negatively impacts both timber and NTFP.

Following IWR 2014 [14], $\triangle \mathrm{NC}$ is qualified by Equation (5):

$$
\Delta N C_{i}(t)=\left\{\begin{array}{lr}
\Delta \text { Fuel }_{J K T}(t), & i=J K T \\
\Delta \operatorname{Crop}_{N C C}(t)+\Delta \operatorname{Tim}_{N C C}(t)+\Delta N T F P_{N C C}(t), & i=N C C
\end{array}\right.
$$

where $\triangle F u e l$ is the change in the stock of fossil fuels caused by improved usage [USD]. This paper follows the same method as IWR 2012 [13] (p. 286) to evaluate the change in fuel stock and estimate the productivity factor per motor vehicle [23,37]. $\Delta$ Crop is the change in the stock value of cropland affected by air pollution [USD]. This paper applies the same method as 2018 [15] (pp. 239-240) to qualify the stock value of cropland, and uses the ExternE method to assess the impacts of air pollutants concentrations [50]. In addition, this paper considers the annual real growth rate of cropland stock in Indonesia, which it estimates as $1.08 \%$ using the nominal stock value growth rate of cropland calculated by the FAO [20] and CPI [34] from 1992 to 2017. $\triangle$ Tim and $\triangle$ NTFP are the changes in the stock values of timber products [USD] and NTFP [USD], and this paper uses IWR 2014 [14] (pp. 211-213). NTFP also includes carbon damage, which is accounted for in adjusted IW [14] (p. 254). Deforestation in the NCC is inevitable; to address this issue, the Indonesian government created the concept of "Forest City" and plans to maintain a minimum of $50 \%$ of the total area as green space [4]. In other words, it is expected that half of the area set aside for the NCC development would be deforested, which is equivalent to around 20,000 ha. In terms of timber value, the NCC would receive benefits for selling timber, offsetting the value of the lost forest. To evaluate these losses, this paper uses the forest rental rate to calculate the value of the lost forest [51]. With respect to NTFP, this paper employs the ecosystem service valuation database [52] as the shadow price. Additionally, this paper sets a $10 \%$ fraction rate which determines the area where people can enjoy NTFP benefits as opposed to the total forest area [53]. The depreciation rates for both timber and NTFP are assumed to be 5\% [14].

\subsubsection{Natural Disaster}

Natural disaster risk is one of the most negative points associated with Jakarta as the national capital city; East Kalimantan was selected as the NCC due to its lower risk. According to Lloyd's City Index $[25,54]$, there are five natural disasters expected in Jakarta, namely, an earthquake, volcano, flood, drought, and tsunami. Among these five disasters, ThinkHazard! [55,56] classifies floods and tsunamis as a high hazard and earthquakes as a medium hazard in East Kalimantan. However, the location of the NCC is surrounded by mountains, which makes the NCC resilient to floods and tsunamis. Moreover, the risk of earthquakes is concentrated in the northeast area of East Kalimantan, an not the southeast, where the NCC is located $[57,58]$. Consequently, natural disaster risk was not calculated in the NCC.

Following Lloyd's City Index, this paper defines the accumulative expected loss due to natural disasters (ND) through Equation (6):

$$
N D_{J K T}(t)=\sum_{\tau=1}^{t} R_{J K T}^{N D} \cdot R G D P_{J K T}(\tau)
$$


where $R_{J K T}^{N D}$ is the ratio of expected annual natural disaster loss to RGDP [\%/year], which is $0.55 \%$ combining the earthquake, volcano, flood, drought, and tsunami risk in Jakarta [25]. $\triangle R G D P_{J K T}$ is the change in regional GDP in Jakarta caused by migration.

\subsubsection{Population Migration and Emission Model}

This paper creates an original model of population migration of employees and their families in the public sector, following Equation (7) to Equation (10):

$$
\begin{gathered}
\Delta \text { PubMgr }_{i}^{15-64}(\mathrm{t})=\left(1+R^{\text {married }}\right) \cdot \Delta \operatorname{Emp}_{i}^{\text {public }}(\mathrm{t}) \\
\Delta \mathrm{PubMig}_{i}^{10-14}(\mathrm{t})=R_{a}^{\text {birth }}(\mathrm{t}) \cdot\left\{\Delta \operatorname{Emp}_{i, a}^{\text {public }}(\mathrm{t}-10)\right\}, \\
\Delta \mathrm{PubMig}_{i}^{5-9}(\mathrm{t})=R_{a}^{\text {birth }}(\mathrm{t}) \cdot\left\{\Delta \operatorname{Emp}_{i, a}^{\text {public }}(\mathrm{t}-5)\right\}, \\
\Delta \mathrm{PubMig}_{i}^{0-4}(\mathrm{t})=R_{a}^{\text {birth }}(\mathrm{t}) \cdot \Delta \operatorname{Emp}_{i, a}^{\text {public }}(\mathrm{t}),
\end{gathered}
$$

where $\Delta P u b M i g^{x-y}$ is the change in population of individuals aged $x$ to $y$ [person]. $\Delta E m p_{a}^{p u b l i c}$ is the change in the number of employees in age group $a$ in the public sector [person]. $R_{a}^{b i r t h}$ is the birth rate per thousand in age group $a$, with data taken from WPP, provided in discrete values every five years [19]. Thus, this paper converts these discrete data into linear data using a single regression model, whose reliability is over $95 \%$ compared with the medium variant of WPP. $R^{\text {married }}$ is the marriage rate [\%], which is $85 \%$ [23].

Figure 6 illustrates the concept of the migration model for public sector employees, and Table 3 and Figure 7 show the results. The result of population prediction in Jakarta and the NCC, depending on the age groups, can be seen in the Appendix A (Figures A1 and A2).

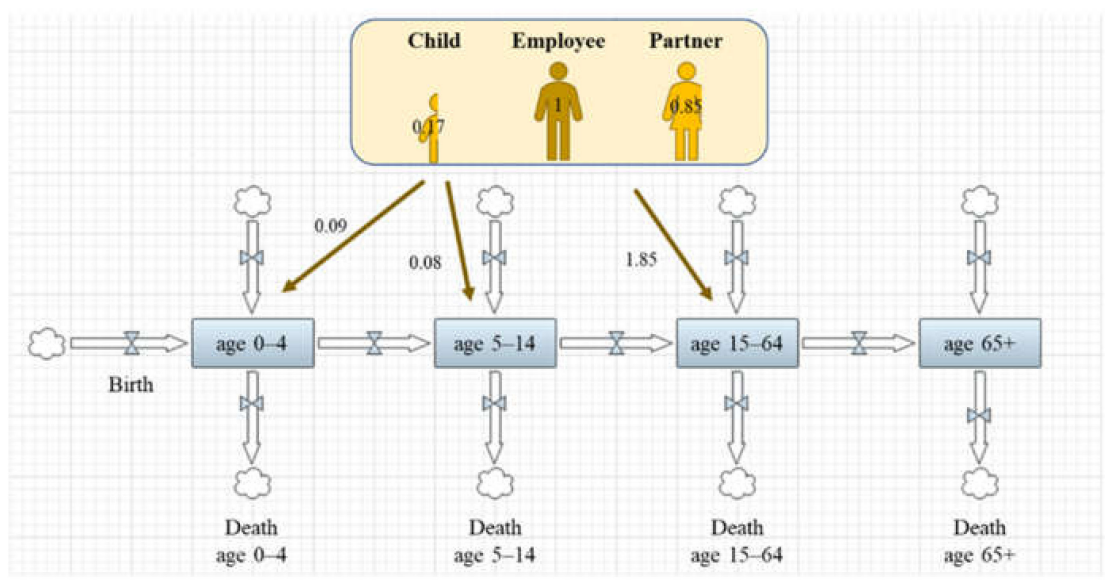

Figure 6. Expected number of migrations per employment in public sector depending on age groups.

Table 3. Average annual child migration rate of public sector employees from 2021 to 2050 [\%].

\begin{tabular}{ccccccc}
\hline & Age 0-4 & Age 5-9 & Age 10-14 & Age 15-19 & Age 20-24 & Age 25-64 \\
\hline 2021-2024 & 4.82 & 34.07 & 5.37 & 5.37 & 25.37 & 19.95 \\
2025-2050 & 9.18 & 3.68 & 0 & 0 & 85.00 & 0 \\
Total & 8.60 & 7.73 & 0.716 & 0.72 & 163.72 & 2.66 \\
\hline
\end{tabular}

Regarding the emission model, this paper considers five air pollutants, namely, $\mathrm{CO}_{2}, \mathrm{CO}, \mathrm{SO}_{2}$, $\mathrm{NO}_{\mathrm{x}}$, and $\mathrm{PM}_{10}$. Table 4 shows the sources of these air pollutants and the variables affected by them. The result of the change in the emissions of each air pollutant in Jakarta and the NCC combined can be seen in the Appendix A (Figure A3). 


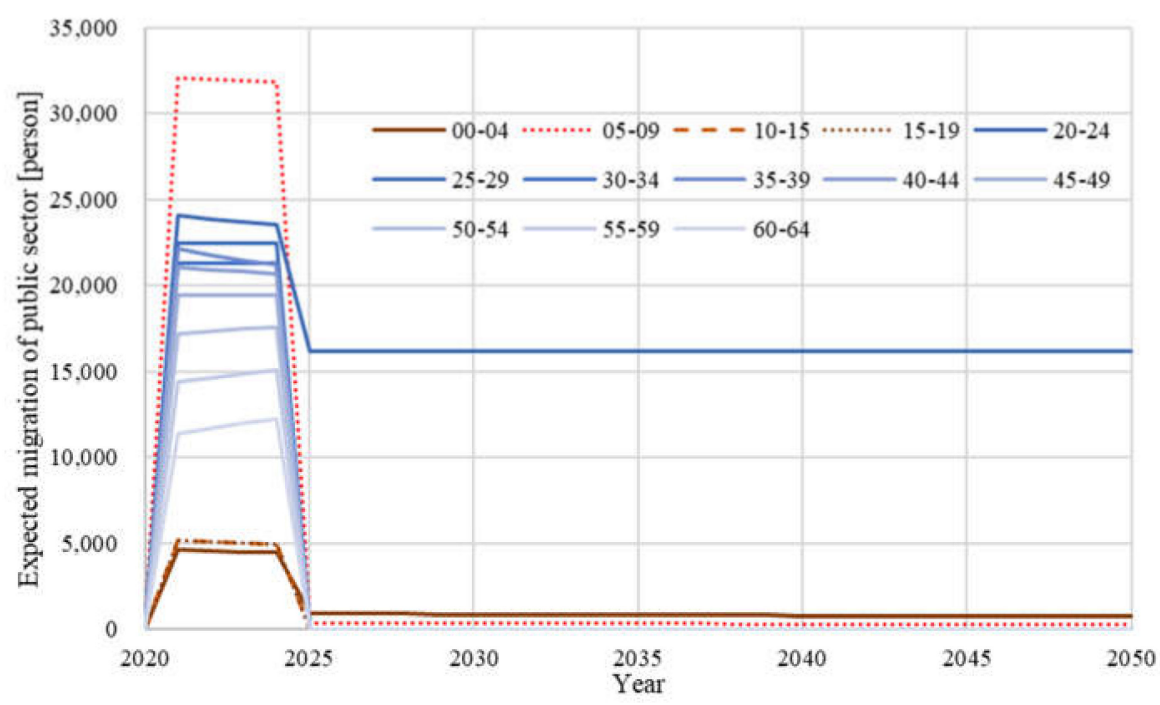

Figure 7. Expected number of migrations of public sector employees and their families [person].

Table 4. Sources of air pollutants and their impacts.

\begin{tabular}{|c|c|c|c|c|c|c|c|c|c|}
\hline & \multicolumn{4}{|c|}{ Sources } & \multicolumn{5}{|c|}{ Impacts } \\
\hline & Construction $^{1}$ & Traffic $^{1}$ & Household $^{1}$ & Deforestation $^{2}$ & Housing $^{3}$ & $\begin{array}{l}\text { Health } \\
\text { Capital }^{4}\end{array}$ & $\begin{array}{l}\text { Medical } \\
\text { Cost }\end{array}$ & $\begin{array}{l}\text { Crop } \\
\text { Yield }^{5}\end{array}$ & $\begin{array}{c}\text { NTFP }^{6} \\
\text { (Carbon Cost) }\end{array}$ \\
\hline $\mathrm{CO}_{2}$ & $\mathrm{~N}$ & & B & $\mathrm{N}$ & & & & & $\mathrm{N}$ \\
\hline $\mathrm{CO}$ & $\mathrm{N}$ & B & & & B & & B & & $\mathrm{N}$ \\
\hline $\mathrm{NO}_{x}$ & $\mathrm{~N}$ & B & B & & & & $\mathrm{B}$ & & \\
\hline $\mathrm{SO} 2$ & $\mathrm{~N}$ & B & & & B & B & B & $\mathrm{N}$ & \\
\hline $\mathrm{PM}_{10}$ & $\mathrm{~N}$ & B & B & & & B & B & & \\
\hline
\end{tabular}

Note: $B$ and $N$ stand for the source or impact in both cities (Jakarta and the NCC) and only the NCC. Data sources:

${ }^{1}$ EDGAR [21,22]. ${ }^{2}$ FAOSTATA [20]. ${ }^{3}$ Yusuf \& Resosudarmo [35]. ${ }^{4}$ Resosudarmo \& Napitupulu (2004) [46].

${ }^{5}$ ExternE [50]. ${ }^{6}$ IWR 2012 [13].

\subsection{Evaluation Indicator for the Results}

Using the original model, this paper evaluates the results of the change in IW using investment efficiency (IE) and the contribution rate (CR).

IE is the indicator used to evaluate each scenario's efficiency of investment compared with a theoretically ideal one, assuming all investment goes to PC. IE and IE per capita are defined by Equation (11) and Equation (12):

$$
\begin{gathered}
I E(t)=\frac{\Delta k(t)}{\sum_{\tau=1}^{t}\left\{\frac{I}{t} \cdot(1-\delta)^{t-\tau-1}\right\}} \times 100 \\
I E \text { per capita }(t)=\frac{\frac{\Delta k(t)}{P_{n}(t)}}{\frac{\sum_{\tau=1}^{t}\left\{\frac{I}{t} \cdot(1-\delta)^{t-\tau-1}\right\}}{P_{B A U}(t)}} \times 100
\end{gathered}
$$

where $\Delta k(t)$ is the change in stock $k$ [USD], which is IWI+, IWI, PC, HC, NC, or ND. I is the amount of total investment throughout time $t[\mathrm{USD}] . \delta$ is the depreciation rate [\%]. $P_{n}$ and $P_{B A U}$ are the population of Scenario $n$ and the BAU scenario, respectively. In this paper, it is assumed to be $4 \%$ (as it is for PC), and $t$ is 30 years during the same simulation period. Thus, the denominator of IE is 360.8 billion USD and that of IE per capita is $36,974 \mathrm{USD} /$ person. 
$\mathrm{CR}$ is the indicator used to evaluate the impact size of each capital stock on IWI+. This paper defines the CR of capital stock $k$ through Equation (13).

$$
C R_{k}(t)=\frac{|\Delta k(t)|}{|\Delta P C(t)|+|\Delta H C(t)|+|\Delta N C(t)|+|\Delta N D(t)|}
$$

\section{Results and Discussion}

\subsection{Model Test}

Sterman (2000) [16] introduces twelve types of model tests to qualify the robustness of SD models. Since some of them are used for pre-modeling, this paper essentially uses three robustness tests, namely, the extreme condition test, the behavior anomaly test, and a sensitivity analysis. In the first two tests, where some parameters have extreme values and some target loops are knocked out, the expected results were obtained; for example, the supposed population migration does not occur at all with the capital city relocation; the change in education capital and GDP fall to zero.

For the sensitivity analysis, best and worst case scenarios are employed. In the best case, all factors are adjusted to push IWI+ up; for instance, emission factors are multiplied by 1.05 in Jakarta and 0.95 in the NCC because Jakarta gains benefits from a reduction in emissions and the NCC suffers the reverse effect. In contrast, all factors are adjusted to make IWI+ worse. For population, the opposed treatment of emission factors is conducted. Figure 8 shows the test results of IWI+, PC, HC, and NC in Scenario 1. Although the base scenarios of $\mathrm{HC}$ and NC are centralized between their best and worst scenarios, this is not true in PC, because of the adjustment of its depreciation rate. In the best case scenario, the depreciation rate is $4 \%$, the same as the base scenario referred to in IWR 2014 [14] and IWR 2018 [15]. On the other hand, the rate of the worst case is 7\%, the same as IWR 2012 [13]. As shown in Figure 8, the depreciation of PC in the worst case scenario is larger than the others, which indicates the importance of the operation and management of PC to decrease its depreciation. The sensitivity of NC is larger than others, which is caused by the adjustment of the deforestation rate. The Indonesian government expects the deforestation rate in the NCC to be 50\% [4]. This paper considers it to be $40 \%$ in the best case scenario and $60 \%$ in the worst case scenario. Hence, the NC loss sensitively corresponds to the deforestation amounts.
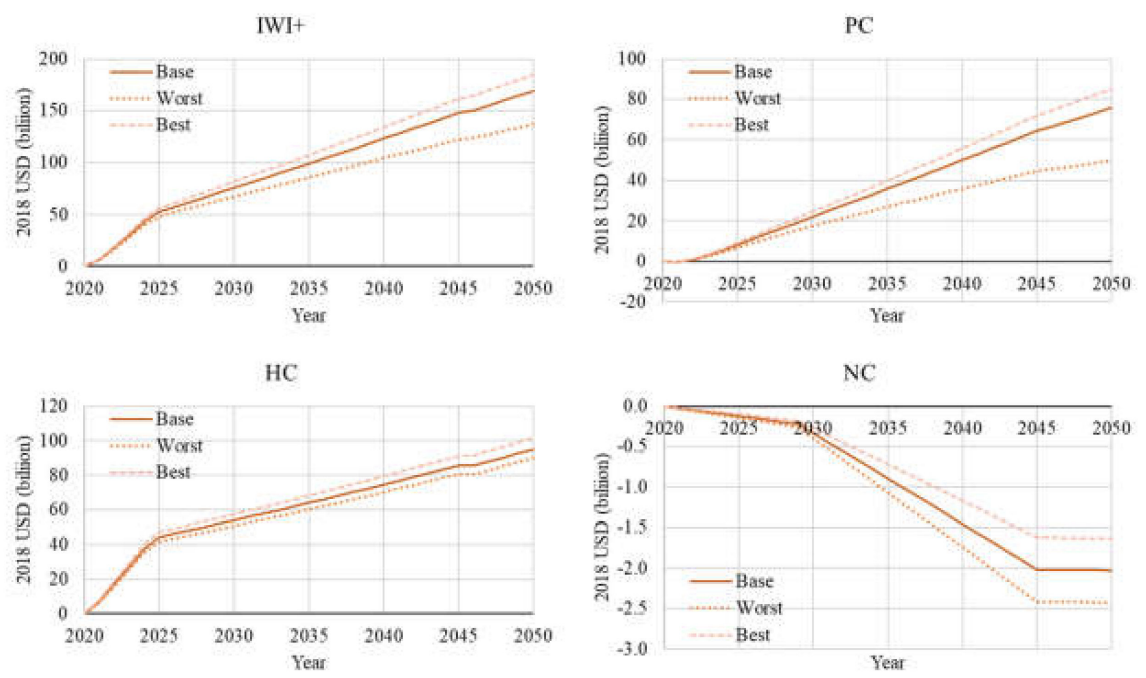

Figure 8. Best and worst scenario tests of the inclusive wealth index + (IWI+), produced capital (PC), human capital (HC), and natural capital (NC) [billion USD] in Scenario 1. 
A sensitivity analysis is also conducted for population and emissions for best and worst analyses. When population sensitivity is tested, emission factors are fixed and only population factors are adjusted. Results show that population has a significant impact on PC, HC, and IWI+; on the other hand, sensitivity to emissions is relatively small in all capitals (see Appendix A, Figures A4 and A5).

\subsection{IWI+, IWI, and Their per Capita}

Figure 9 shows the change in IWI+, IWI, and their value per capita combined for Jakarta and the NCC in each scenario. All graphs are comparable: (i) the similarity between the gross and per capita value illustrates that wealth growth is adequate compared to population growth; and (ii) that between IWI+ and IWI indicates that the benefit of mitigating natural disaster risk through relocation is relatively small compared with the impacts of other capital stocks (Figure 10). In 2050, Scenario 1 and Scenario 2 have positive values and Scenario 3 has a negative value. The change in IWI+ in Scenario 1 in 2050 amounts to 169 billion USD, which is equivalent to $2.41 \%$ of the cumulative amount of real GDP growth in Indonesia from 2021 to 2050; that in Scenario 2 amounts to 76.8 billion USD; and that in Scenario 3 amounts to -8.08 billion USD. Furthermore, Scenario 1 and Scenario 2 show a monotonic increase even after the capital city relocation project finishes, in 2045, owing to the population recovery in Jakarta and increased immigrants into the NCC from outside the concerned system. In contrast, the Scenario 3 trend moves around the $x$ axis and shows a monotonic decrease after 2045, which means it is not sustainable in the long run. As for the IWI+ per capita, the change in Scenario 1 in 2050 amounts to 6763 USD per capita, that in Scenario 2 to 3439 USD per capita, and that in Scenario 3 to -297 USD per capita.

Scenario 1 has a $28.8 \%$ investment efficiency in IWI, and Scenario 3 has $-1.1 \%$ (Table 5 ). Therefore, the capital city relocation brings benefits to Jakarta and the NCC (or inside the concerned system); however, once the area outside the system is considered, the change is not reasonable, because the benefits gap between Scenario 1 and Scenario 3 might be exploited from outside the system through migration. When the evaluation includes the impacts outside the system, the study area should be expanded, and a more detailed population model is required.
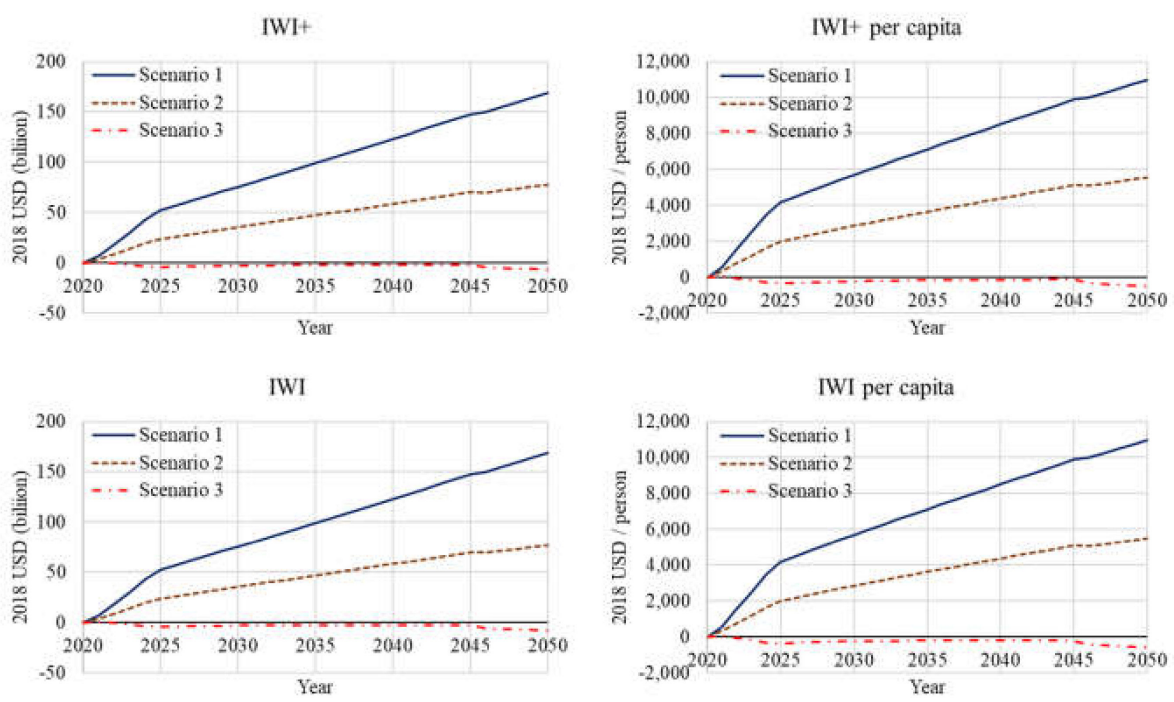

Figure 9. The change in gross IWI+ [billion USD], IWI+ per capita [USD/person], IWI [billion USD], and IWI per capita [USC/person]. 


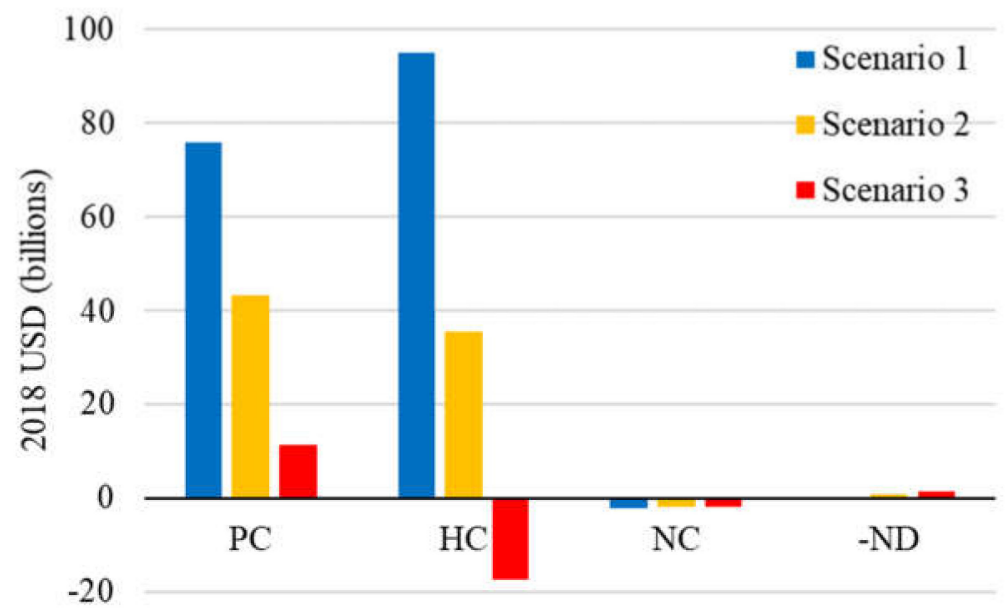

Figure 10. The change in stock value of PC, HC, NC, and less natural disasters (-ND) in 2050 [billion USD].

Table 5. Investment efficiency (IE) of IWI and IWI per capita [\%].

\begin{tabular}{|c|c|c|c|c|c|c|c|c|c|c|c|c|}
\hline & \multicolumn{6}{|c|}{ IE } & \multicolumn{6}{|c|}{ IE Per Capita } \\
\hline & IWI+ & IWI & PC & HC & NC & ND & IWI+ & IWI & PC & $\mathrm{HC}$ & NC & ND \\
\hline Scenario 1 & 46.85 & 46.81 & 21.02 & 26.35 & -0.56 & 0.04 & 40.74 & 40.70 & 18.28 & 22.91 & -0.49 & 0.04 \\
\hline Scenario 2 & 21.52 & 21.28 & 11.98 & 9.86 & -0.55 & 0.23 & 20.60 & 20.38 & 11.18 & 9.71 & -0.51 & 0.22 \\
\hline Scenario 3 & -1.81 & -2.24 & 3.13 & -4.84 & -0.54 & 0.43 & -1.81 & -2.24 & 3.13 & -4.84 & -0.54 & 0.43 \\
\hline
\end{tabular}

\subsection{PC and PC per Capita}

Figure 11 shows the change in gross PC and PC per capita in each scenario. Scenario 3 has the highest value of PC. The value of change in the PC stock of Scenario 1 in 2050 is 75.8 billion USD, while the CR of Scenario 1 is $43.82 \%$; that of Scenario 2 is 43.2 billion USD, while the CR is $52.95 \%$; and that of Scenario 3 is 17.45 billion USD, while the CR is $35.07 \%$ (Figure 12). This is because a larger population entails greater household spending, which generates investment through increased GDP. Although a larger population leads to an increase in congestion, emissions, and natural disaster risk, population growth brings overall benefits to PC. The trend's turning point will occur in 2045, at the time when the capital city development is completed and the depreciation of the infrastructure starts to stand out. Since the best and worst scenario tests in Section 3.1 show that PC sensitively responds to the depreciation rate, better management and continuous investment are necessary in order to maintain the sustainability of PC after 2045.
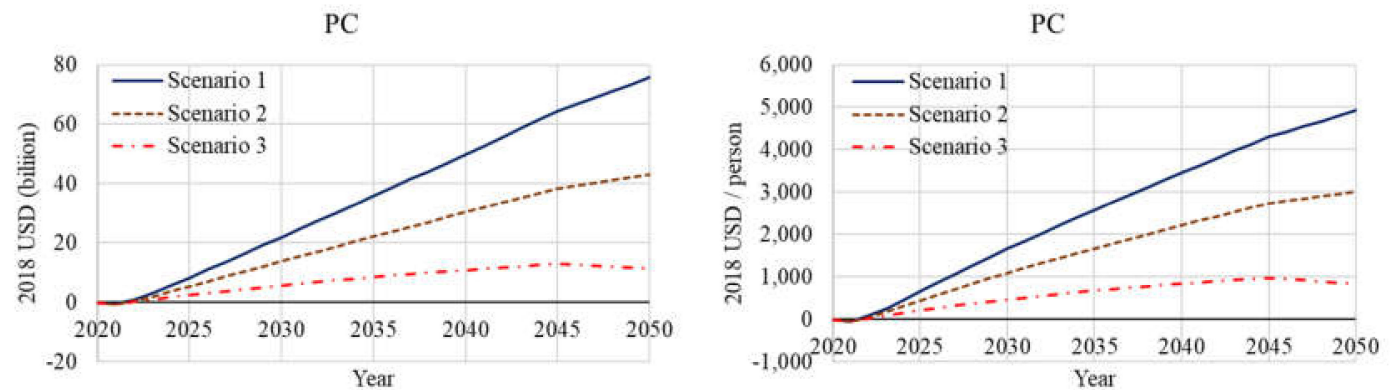

Figure 11. The change in gross PC [billion USD] (left) and PC per capita [USD/person] (right). 

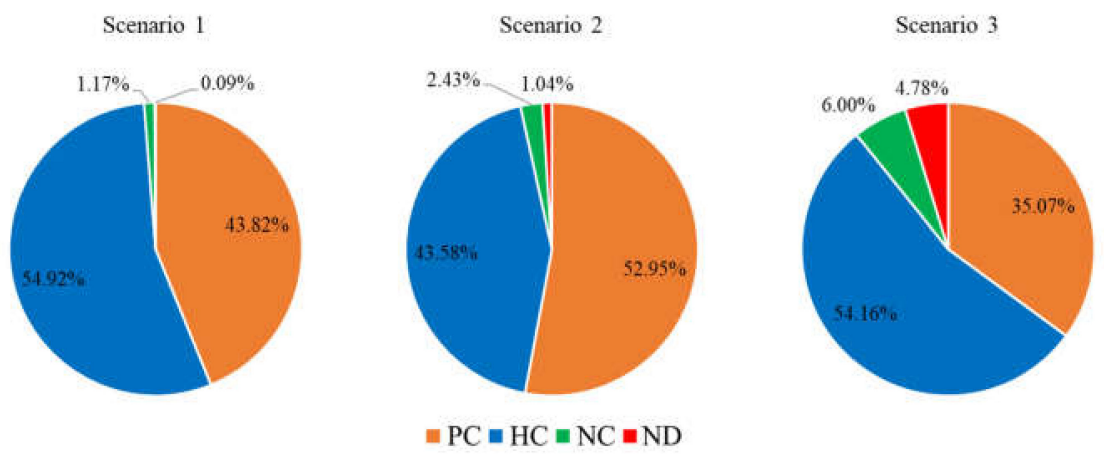

Figure 12. The contribution rate (CR) to IWI and IWI per capita of the three capital stocks depending on three scenarios in 2050 [\%].

\subsection{HC and HC per Capita}

Figure 13 shows the change in gross HC and HC per capita in each scenario. Both trajectories are similar to those of IWI and IWI per capita. HC has the largest fluctuation between scenarios (Figure 10), which means it has the strongest impacts on IWI in all scenarios, as the sensitivity analysis shows. The HC value of Scenario 1 in 2050 is 95.1 billion USD, while the CR is $54.92 \%$; that of Scenario 2 is 35.6 billion USD, while the CR is $43.58 \%$; and that of Scenario 3 is -17.5 billion USD, while the CR is $54.16 \%$.
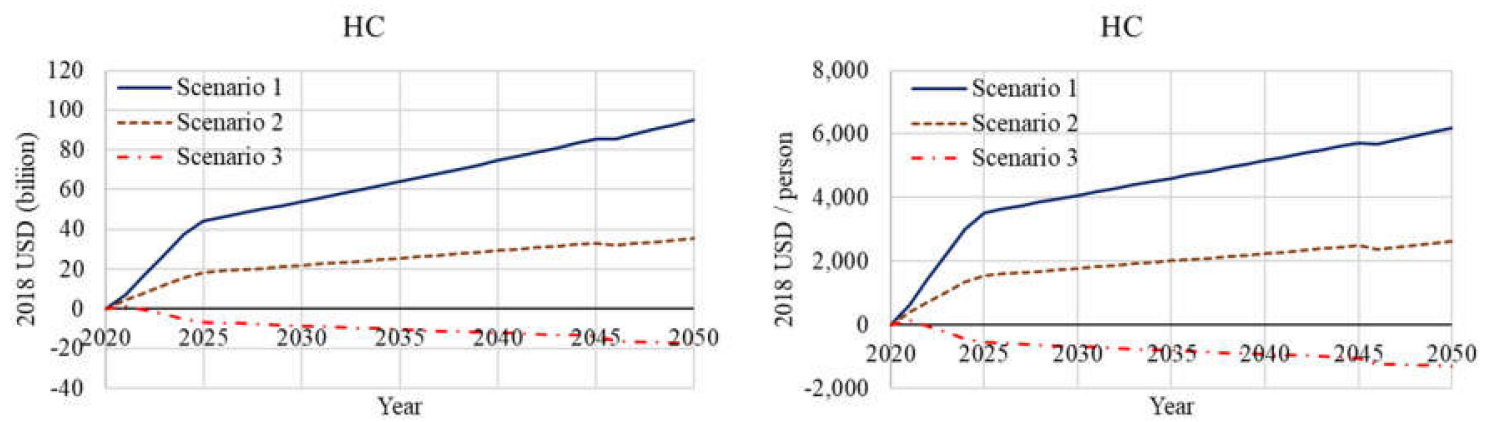

Figure 13. The change in gross HC [billion USD] (left) and HC per capita [USD/person] (right).

From the definition of the three scenarios determined by the increased immigration from outside the concerned system, Figure 10 is considered to be the result of a sensitivity analysis of population size. Since education capital is defined by the size and structure of the population, including age distribution, educational attainment, and wages [13], the gap between Scenario 1 and Scenario 3 becomes large. This stock gap is mainly brought from outside the system, through migrants, because education capital plays a significant role in HC (as discussed later), which means that the market outside the system loses stocks at the same time that gains are found inside the system. In other words, this stock gap is interpreted as exploitation from the outside.

\subsection{NC and NC per Capita}

Figure 14 shows the change in gross NC and NC per capita for each scenario. In contrast to the PC, all three trends had negative values throughout the simulation period; in other words, there is a trade-off effect between PC and NC, as has also been validated in previous IWRs [13-15]. However, the CR of NC is small in all scenarios (Figure 12). Furthermore, the decline of NC stops in 2045, and NC per capita then improves in line with population growth. However, these findings should be carefully interpreted, as the criticality and resilience of $\mathrm{NC}$ are not accounted for, and it is impossible to restore primary rainforests once destroyed [59]. First, the NCC is located in one of the largest tropical rainforests in the world (after the Amazon and Congo rainforests). Furthermore, it is the largest peat 
swamp forest, so it is impossible to restore it once it is destroyed, unlike other capital stocks [60]. Since NC is sensitive to the area of deforestation, as Figure 8 shows, maximum efforts to decrease deforestation should be put into action.
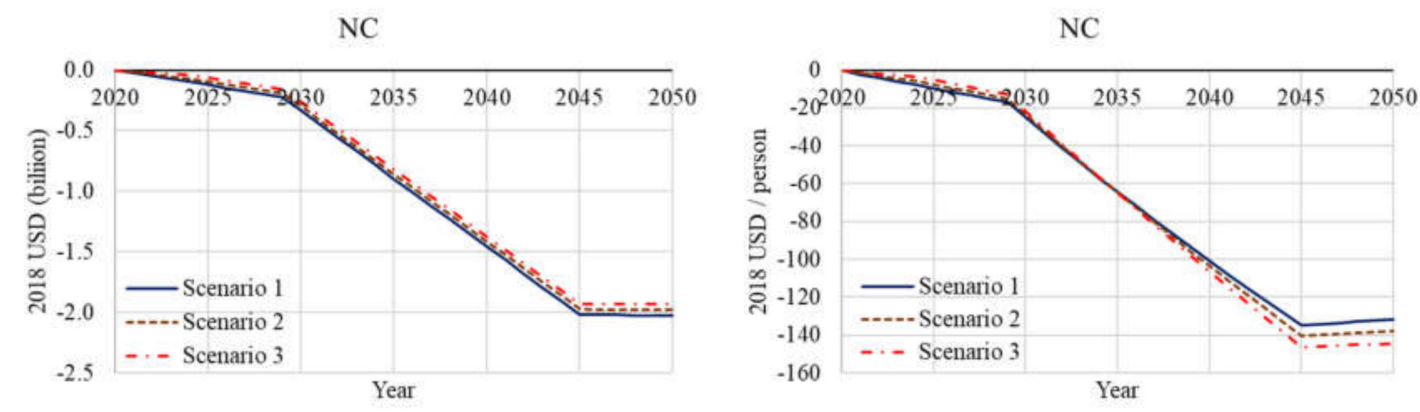

Figure 14. The change in gross NC [billion USD] (left) and NC per capita [USD/person] (right).

\subsection{Scenario 1-The Most Reliable Scenario}

Figure 15 shows the IWI and IWI per capita in Jakarta, the NCC, and their aggregate in Scenario 1. As for IWI, the curves for Jakarta and the NCC are symmetrical on the $x$ axis, which means the NCC receives benefits from the relocation, while Jakarta loses a similar amount of stocks. In other words, there is a trade-off effect between Jakarta and the NCC, but the total benefits of the relocation are positive. When examining the IWI per capita there is no symmetry, but the NCC seemed to gain larger benefits than Jakarta. This difference is caused by the population gap between the two cities; accordingly, the aggregate value colored in red does not trace the center between two curves of Jakarta and the NCC.
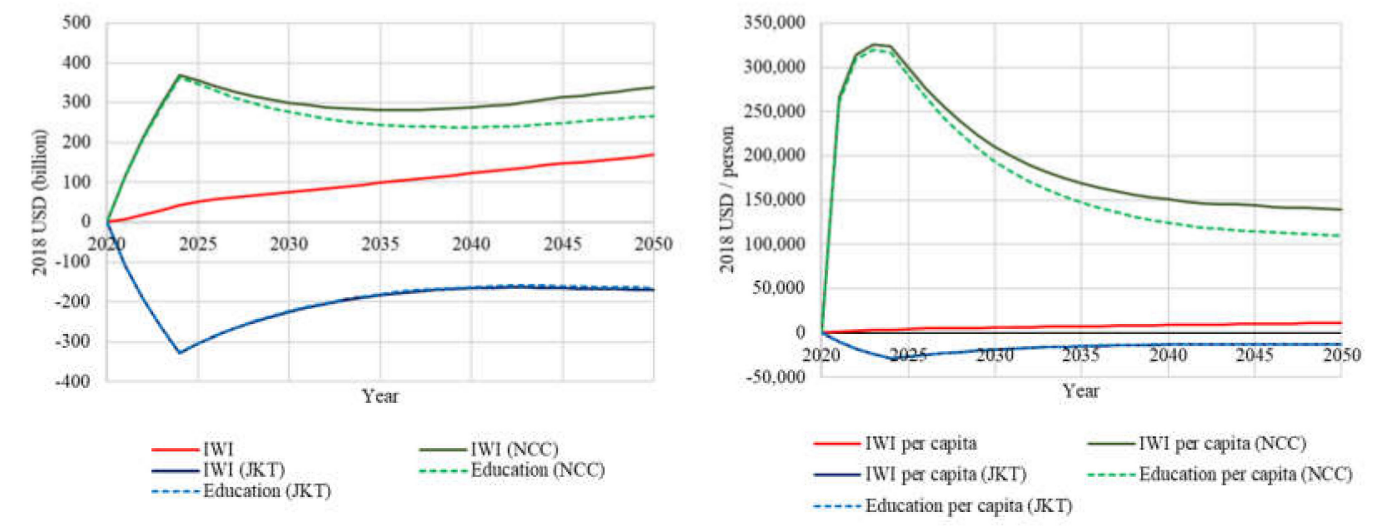

Figure 15. The change in gross IWI [billion USD] in total, Jakarta and NCC (left), and IWI per capita [USD/person] in total, Jakarta and NCC (right) in Scenario 1 [billion USD].

\subsection{Scenario 3-Sustainability Evaluation}

This paper evaluates the sustainability of the capital city relocation itself using Scenario 3, so as to exclude the impact of migration from outside the system, which entails the transfer of IW between the inside and the outside of the system. Figure 16 shows the change in gross IWI+, IWI, and their per capita rates for Scenario 3, with two similar time trends. IWI and IWI per capita are mostly negative throughout the simulation period. The change in gross IWI+ in 2050 amounts to -6.54 billion USD, and that in IWI per capita to -489 USD/person. In addition, the trendlines following the completion of the development of the NCC in 2045 show a monotonic decrease. As a result, the current plan of capital city relocation in Indonesia does not adequately ensure the sustainability of the project. 

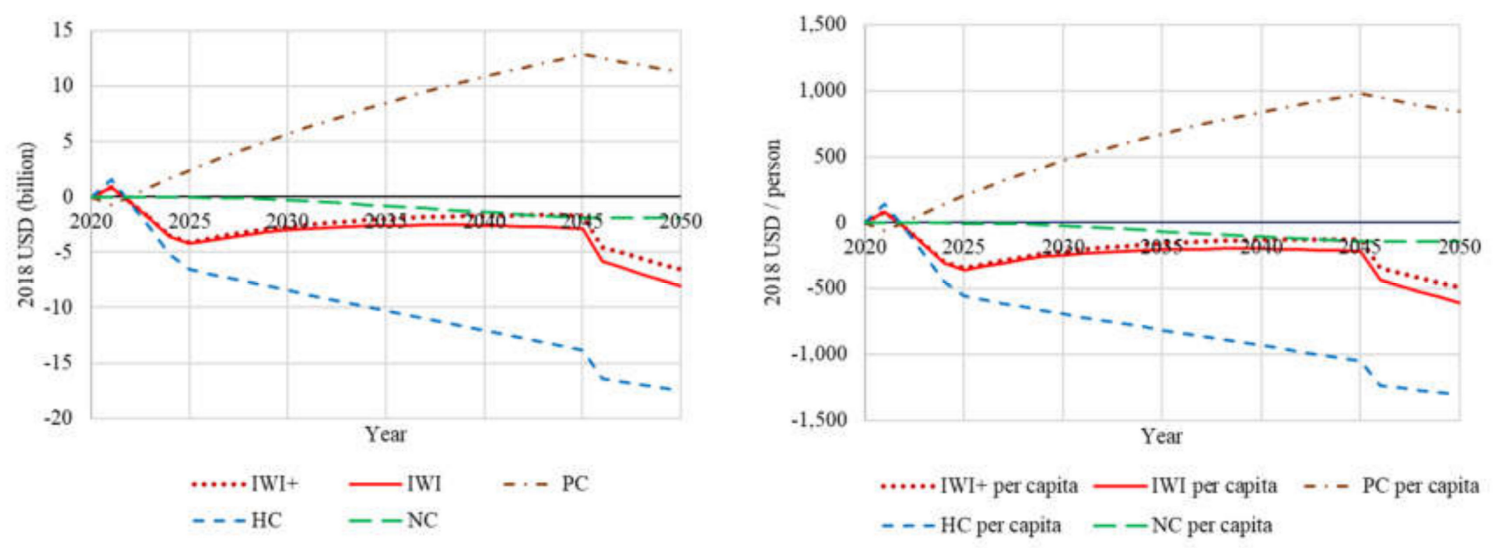

Figure 16. The change in gross IWI+, IWI, and three capital stocks in Scenario 3 [billion USD].

For HC, which is the most negative factor in IWI, as Figure 16 shows, education capital plays the most significant role in a declining HC (Figure 17). The degradation of education capital is caused by the income gap between Jakarta and the NCC. Hence, the expected rise in income level of the NCC will improve education capital and IW.
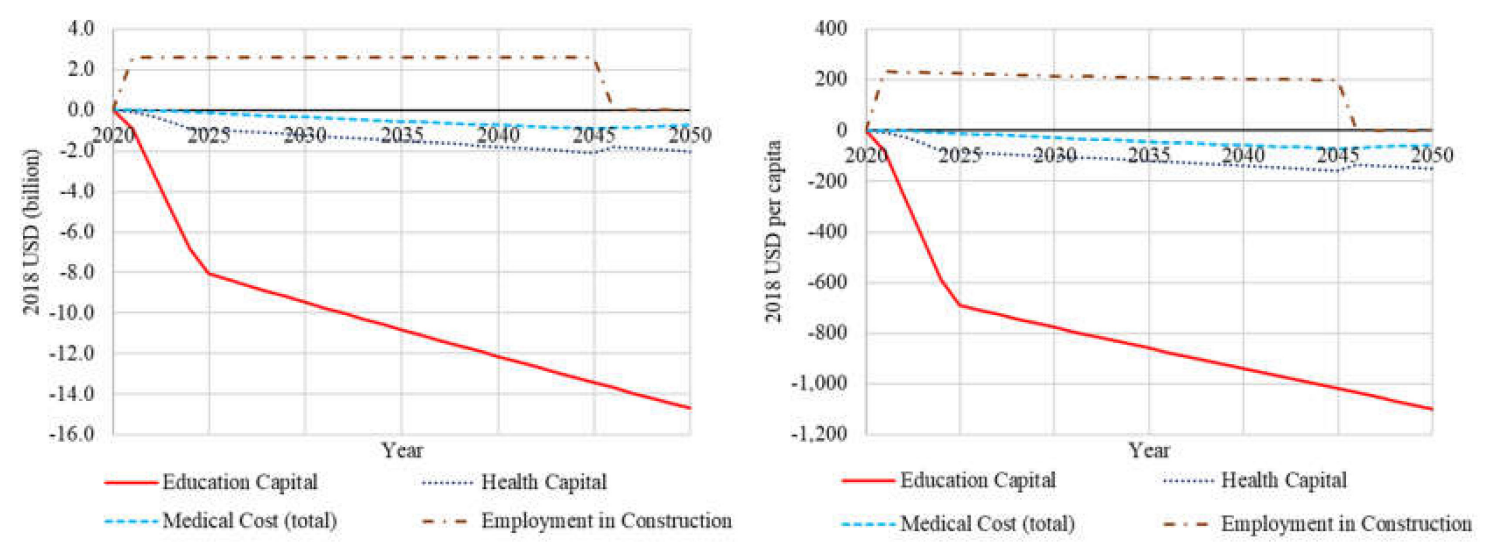

Figure 17. The outbreak of HC [billion USD] (left) and HC per capita [USD/person] (right) in Scenario 3.

Impacts of Income Level in the NCC on Education Capital, HC, IWI, and Their per Capita

Education capital has the largest impact on the sustainability of Scenario 3, as shown above. This paper simulates seven cases, changing the mean annual individual income in the NCC from the current level in the NCC to that in Jakarta (see Section 2.5). The result of education capital and its per capita are shown in Figure 18, that of HC and its per capita are illustrated in Figure 19, and that of IWI and IWI per capita are presented in Figure 20.

As for education capital, Case 6 can ensure sustainability in the concerned system. In Case 6, whose income level in the NCC is the same as that in Jakarta, the change in education capital starts to be positive in the 2040s, with a slightly monotonic increase from the 2030s. Although Case 4 and Case 5 seem flat, they tend to a slightly monotonic decrease, which is considered unsustainable. This happens in education capital per capita as well. Therefore, to ensure the sustainability of education capital and its per capita, the income level in the NCC should be raised to 1.17 times that in Jakarta. 

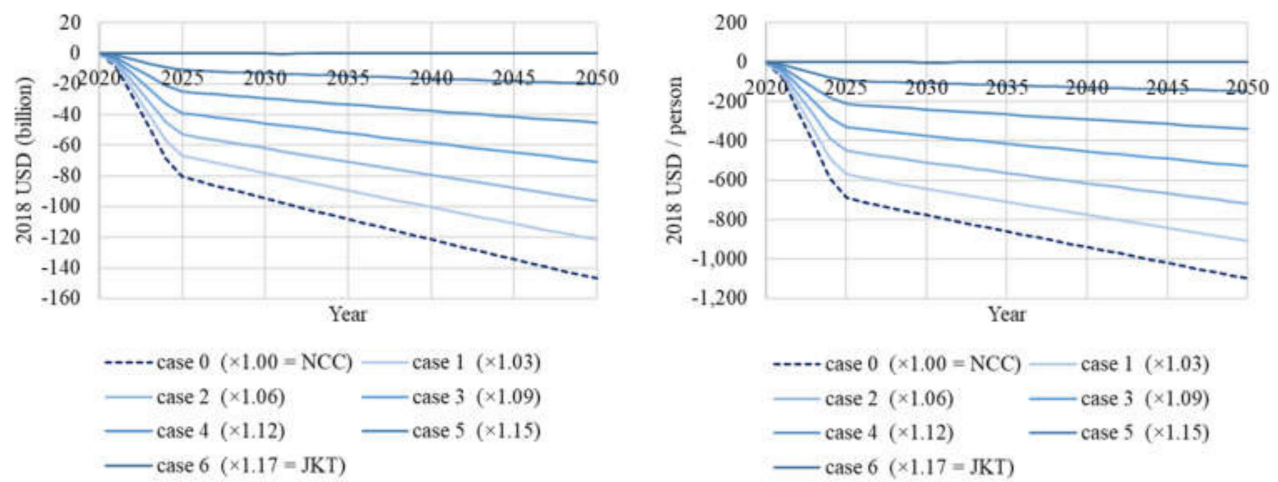

Figure 18. The change in education capital [billion USD] (left) and its per capita [USD/person] (right) in Scenario 3 depending on the income level in the NCC, from the current NCC's level $(\times 1.00)$ to Jakarta's level $(\times 1.17)$.
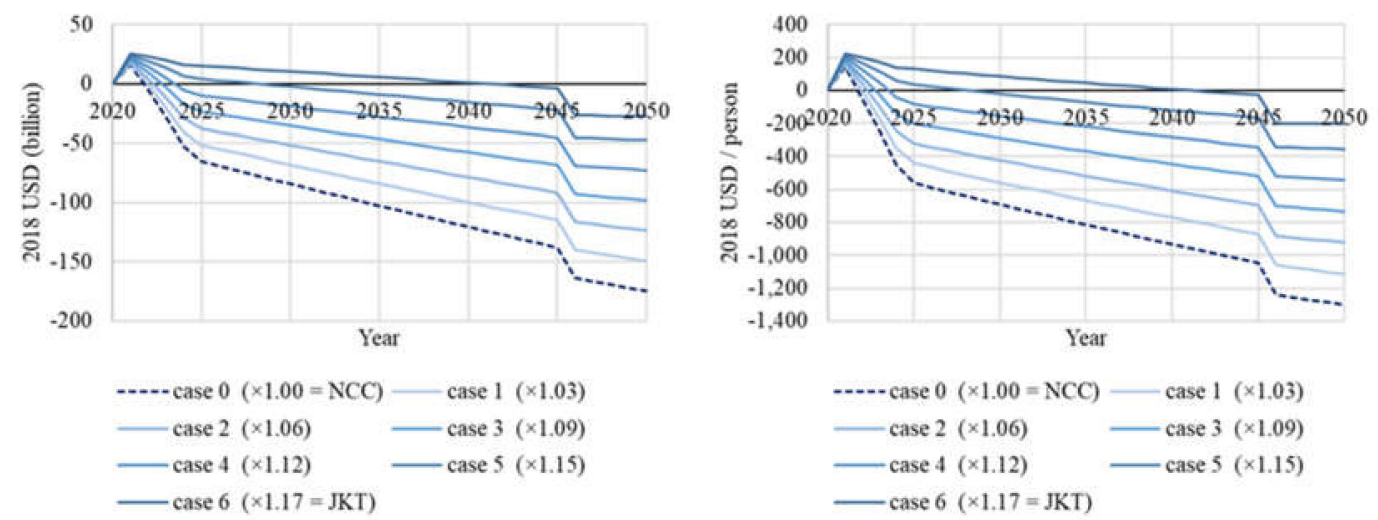

Figure 19. The change in HC [billion USD] (left) and its per capita [USD/person] (fight) in Scenario 3 depending on the income level in the NCC from the current NCC's level $(\times 1.00)$ to Jakarta's level $(\times 1.17)$.

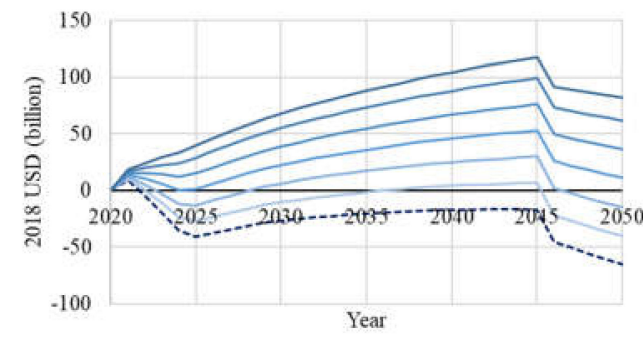

$\begin{array}{ll}--- \text { case } 0(\times 1.00=\mathrm{NCC}) & \text { case } 1(\times 1.03) \\ - \text { case } 2(\times 1.06) & \text { case } 3(\times 1.09) \\ - \text { case } 4(\times 1.12) & \text { case } 5(\times 1.15) \\ -\operatorname{case} 6(\times 1.17=\mathrm{JKT}) & \end{array}$

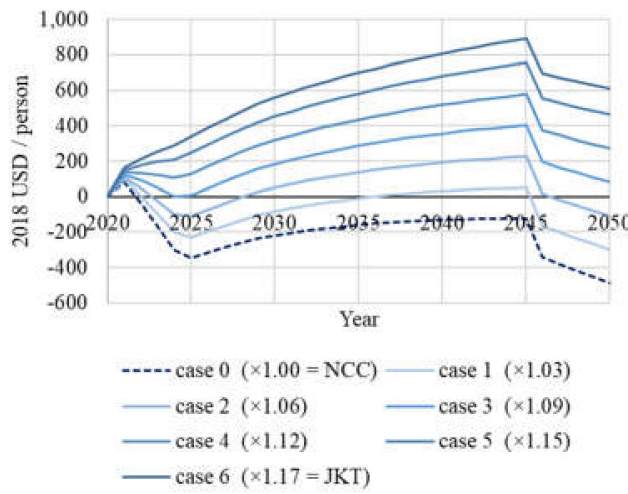

Figure 20. The change in IWI [billion USD] (left) and its per capita [USD/person] (right) in Scenario 3 depending on the income level in the NCC from the current NCC's level $(\times 1.00)$ to Jakarta's level $(\times 1.17)$.

With respect to HC and HC per capita, the decline after 2045 is inevitable once temporary employment in the construction sector diminishes as the development project is completed. Although the monotonic decreases get worse even after 2045, no case has a monotonic increase trend or positive value in 2050 .

Regarding IWI+, four cases (Case 3 to Case 6) have a positive value in 2050; however, there is no case with a trending monotonic increase after 2045, which means the sustainability of IWI cannot be guaranteed in the long run. Long-term sustainability is only possible after 2045, when the income level in the NCC exceeds that in Jakarta. In other words, additional investment is required to secure the 
sustainability of IW. The situation of IWI+ per capita is the same as that of IWI; although five cases (Case 3 to Case 6) have positive values throughout the simulation period, no case ensures sustainability after 2045.

In summation, to attain the sustainability of education capital and its per capita, an income level at least 1.17 times the current level, which is the same as that in Jakarta, is required (Case 6). However, even the income level of Jakarta (Case 6) is not adequate to sustain HC, IWI+, and their per capita (Table 6). Decreasing the income gap between Jakarta and the NCC does not help enhance sustainability, as observed in the trends between cases, which remain parallel even though the values are improved. This means that the sustainability of education capital, HC, and IWI+ do not sensitively respond to increased income levels in the NCC when the maximum income level is fixed at that of Jakarta. Furthermore, a ranging minimum wage might bring other problems, like inflation and unemployment, to the NCC. Therefore, other policies, such as a better maintenance of PC and the improvement of the education level in the NCC, must be implemented.

Table 6. The bottom line of the cases and their adjusted factors of income level for sustainability in the long run and positive value in 2050 in terms of education capital, HC, IWI, and their per capita.

\begin{tabular}{ccccc}
\hline & \multicolumn{2}{c}{ Sustainability in Long Run } & \multicolumn{2}{c}{ Positive Value in 2050 } \\
\cline { 2 - 5 } & Case & Adjusted Factor & Case & Adjusted Factor \\
\hline Edu $^{1}$ & Case 6 & 1.17 & Case 6 & 1.17 (JKT) \\
$\mathrm{HC}^{2}$ & N/A & - & N/A & - \\
IWI+ ${ }^{3}$ & N/A & - & Case 3 & 1.09 \\
\hline Edu per capita & Case 6 & $1.17(\mathrm{JKT})$ & Case 6 & 1.00 (NCC) \\
HC per capita & N/A & - & N/A & - \\
IWI+ per capita & N/A & - & Case 3 & 1.09
\end{tabular}

Note: ${ }^{1}$ Edu is education capital [13] (pp. 281-282). 2,3 HC and IWI+ are human capital defined by Equation (4) and inclusive wealth index defined by Equation (2), respectively.

\section{Conclusions and Recommendation}

The most reliable scenario (Scenario 1) has 169 billion USD in stock value of IWI+ in 2050, which is equivalent to $2.41 \%$ of the cumulative amount of real GDP growth in Indonesia from 2021 to 2050 and 10,988 USD of IWI+ per capita in 2050. In Scenario 1, although Jakarta is negatively affected as regards stock assets, the combined value between Jakarta and the NCC is positive. Therefore, the capital city relocation in Indonesia brings total benefits both in IW and IW per capita to the concerned system. On the other hand, these benefits are mainly supplied by immigrants from outside the system, which implies the loss of capital stock outside the system. There are trade-off effects between NC and PC, but the degradation in NC can be considered relatively small compared with the other benefits.

Regarding the sustainability of the capital city relocation itself, current investment plans are not adequate to ensure the sustainability of the results for IWI+ and IWI+ per capita (Scenario 3), largely because education capital has significant negative effects owing to the income gap between Jakarta and the NCC. Thus, it will be possible to improve the situation by increasing the income level (the mean annual individual income). For example, making the income level in the NCC equal to that in Jakarta (Case 6), the sustainability of education capital and its per capita are retained. However, even with 1.17 times the current income level (Case 6), which is equivalent to the income level in Jakarta, the sustainability of HC, IWI+, and their per capita are not guaranteed. This is because income level plays a role in improving stock values; on the other hand, sustainability is not sensitive to income level.

In terms of sensitivity analysis, each capital asset sensitively and significantly responds to the change in population size, depreciation rate, and deforestation area. Therefore, improving the maintenance of $\mathrm{PC}$ and preventing deforestation are effective for sustainability. Furthermore, migration policy is very important, not only because population has significant impacts on this topic but also because migration is equal to the transfer of capital assets. In order to detect the optimal point of 
migration policy and ensure sustainability both inside and outside of the concerned system, advanced study is required.

This study has, of course, limitations. For instance, this paper focuses on Jakarta and the NCC as the concerned system. Hence, it does not evaluate the impact of relocation outside the system. Although IW includes NC as an integrated index, it is still challenging to account for the criticality and resilience of NC [59]. With regard to natural disaster risk, it has been estimated how economic scale plays a role in resilience, but not economic structure. Above all, data accessibility is critical; for instance, it is impossible to obtain time series data at a local level, such as population and emissions, even though this paper uses those at the country level. In order to improve the reliability of the study, qualified data are obviously required. However, this study makes a significant contribution to the relevant policy evaluation literature, especially because there are still few evaluations of capital city relocations and because it considers the impact of migration on IW and its sustainability.

Author Contributions: Conceptualization, T.S.; supervision, T.M.; formal analysis, T.S.; model building, T.S.; writing-original, T.S.; writing-review and editing, T.S. and T.M. All authors have read and agreed to the published version of the manuscript.

Funding: This research received no external funding.

Acknowledgments: We would like to thank Editage for English language editing.

Conflicts of Interest: The authors declare no conflict of interest.

\section{Appendix A}
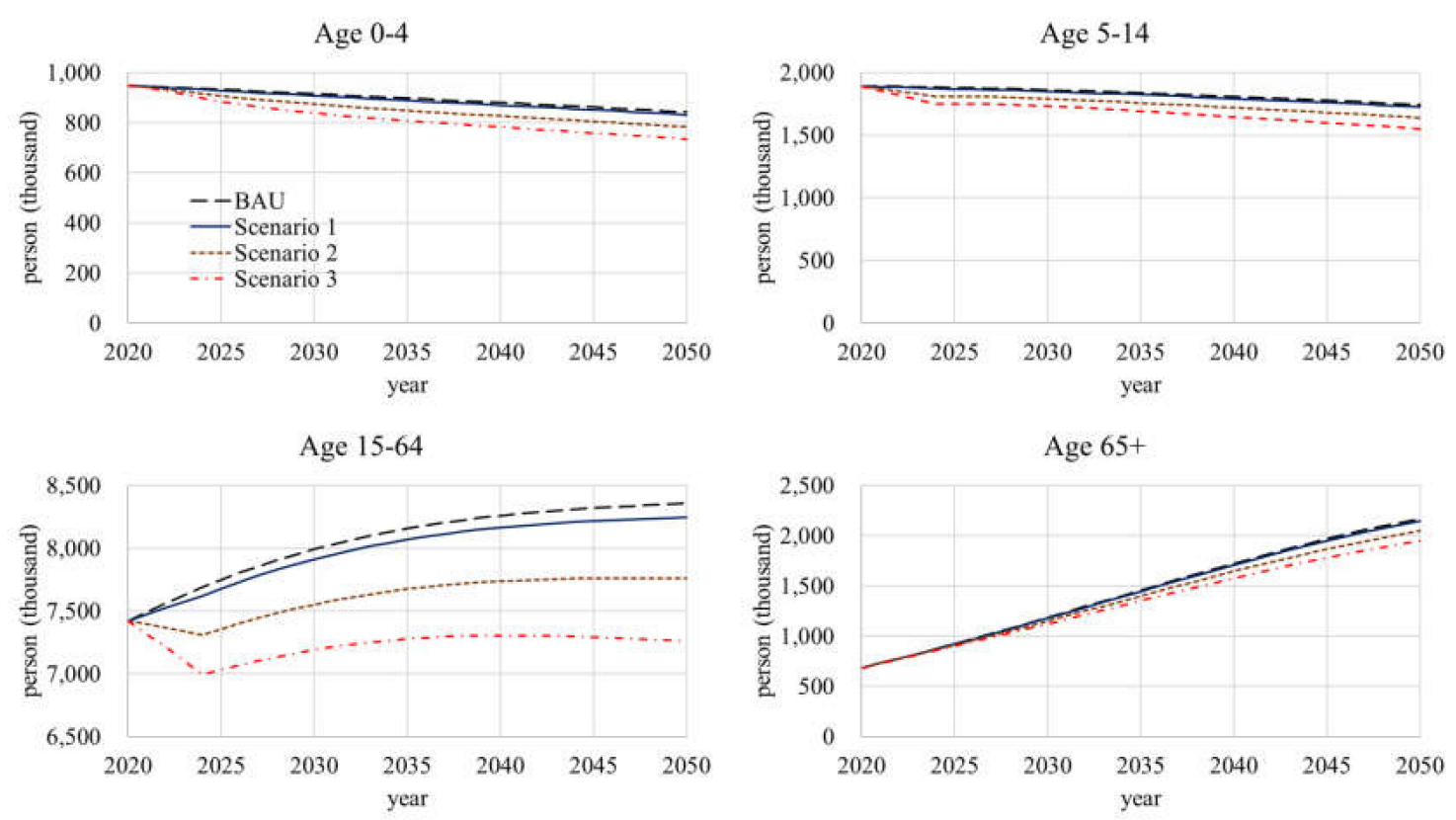

Figure A1. The estimated population in Jakarta for four age groups [thousand people]. 
Age 0-4

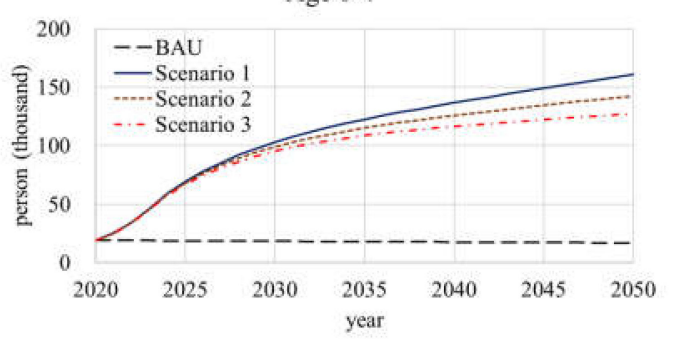

Age 15-64

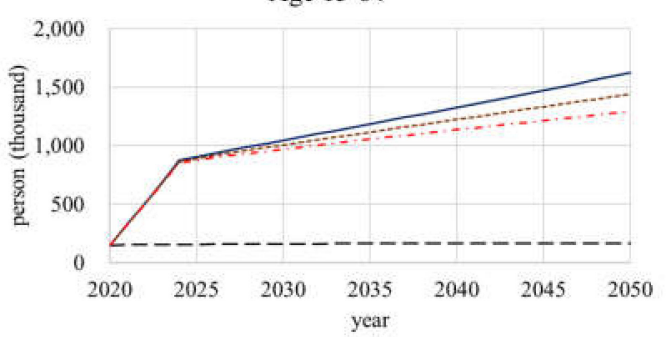

Age 5-14

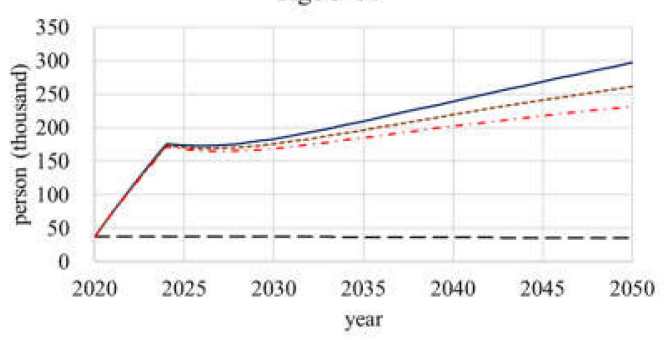

Age 15-64

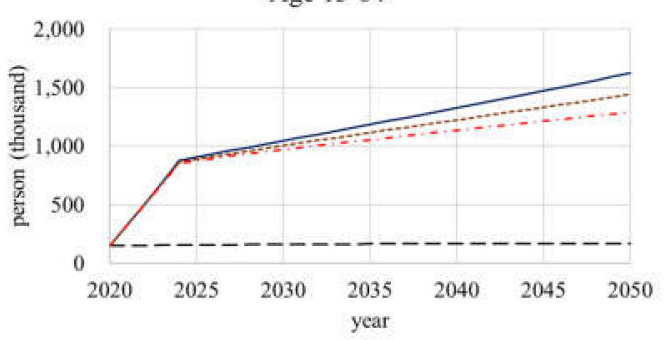

Figure A2. The estimated population in the NCC for four age groups [thousand people].

$\mathrm{CO} 2$

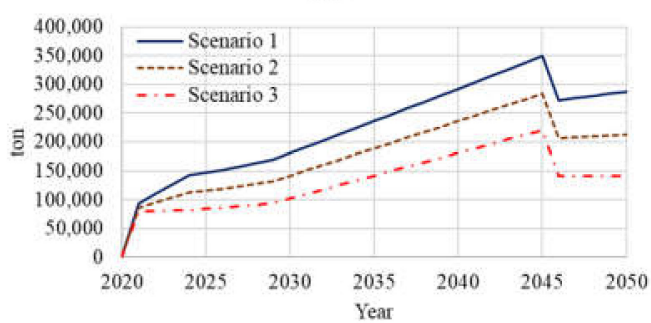

$\mathrm{SO} 2$

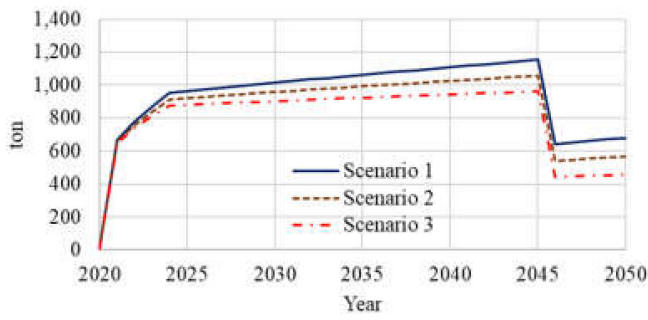

PM10

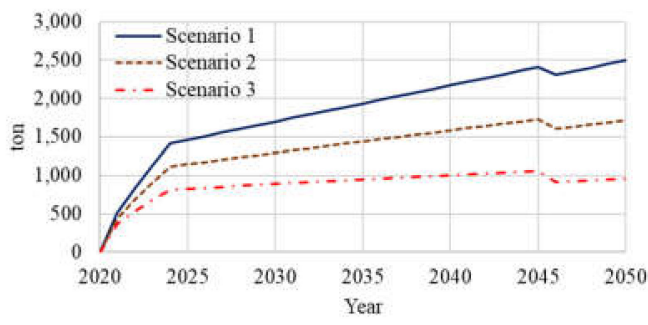

$\mathrm{CO}$

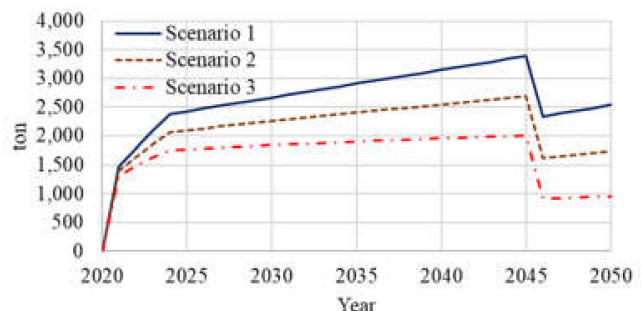

NOx

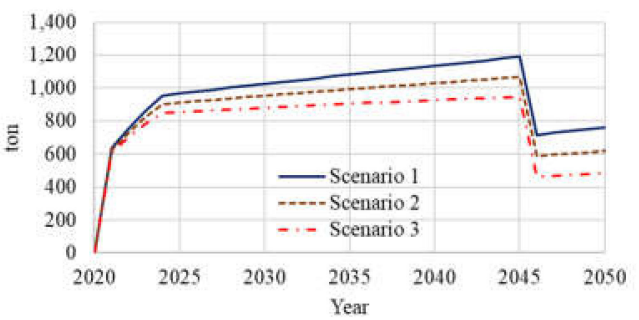

Figure A3. The estimated change in the emissions of each air pollutant, namely, $\mathrm{CO}_{2}, \mathrm{CO}, \mathrm{SO}_{2}, \mathrm{NO}_{\mathrm{x}}$, and $\mathrm{PM}_{10}$ [ton], in Jakarta and the NCC combined. 
IWI+

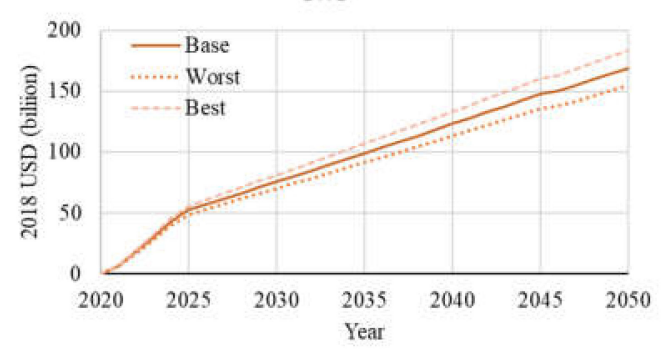

$\mathrm{HC}$

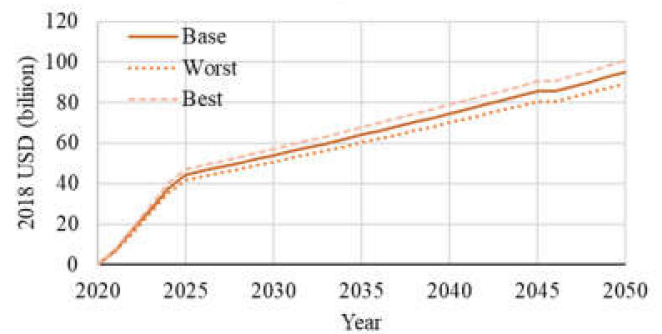

PC

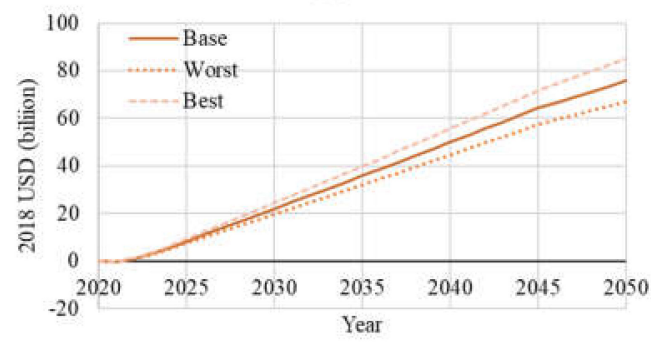

$\mathrm{NC}$

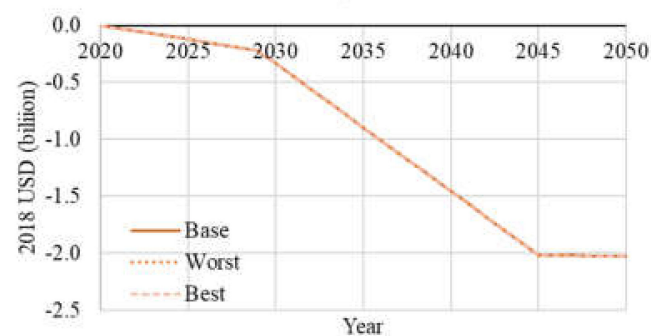

Figure A4. Sensitivity analysis for population in Scenario 1 [billion USD]. In the best scenario, population factors are multiplied by 0.95 in Jakarta and 1.05 in the NCC, respectively. In the worst scenario, the opposed adjustment of the best scenario is done.
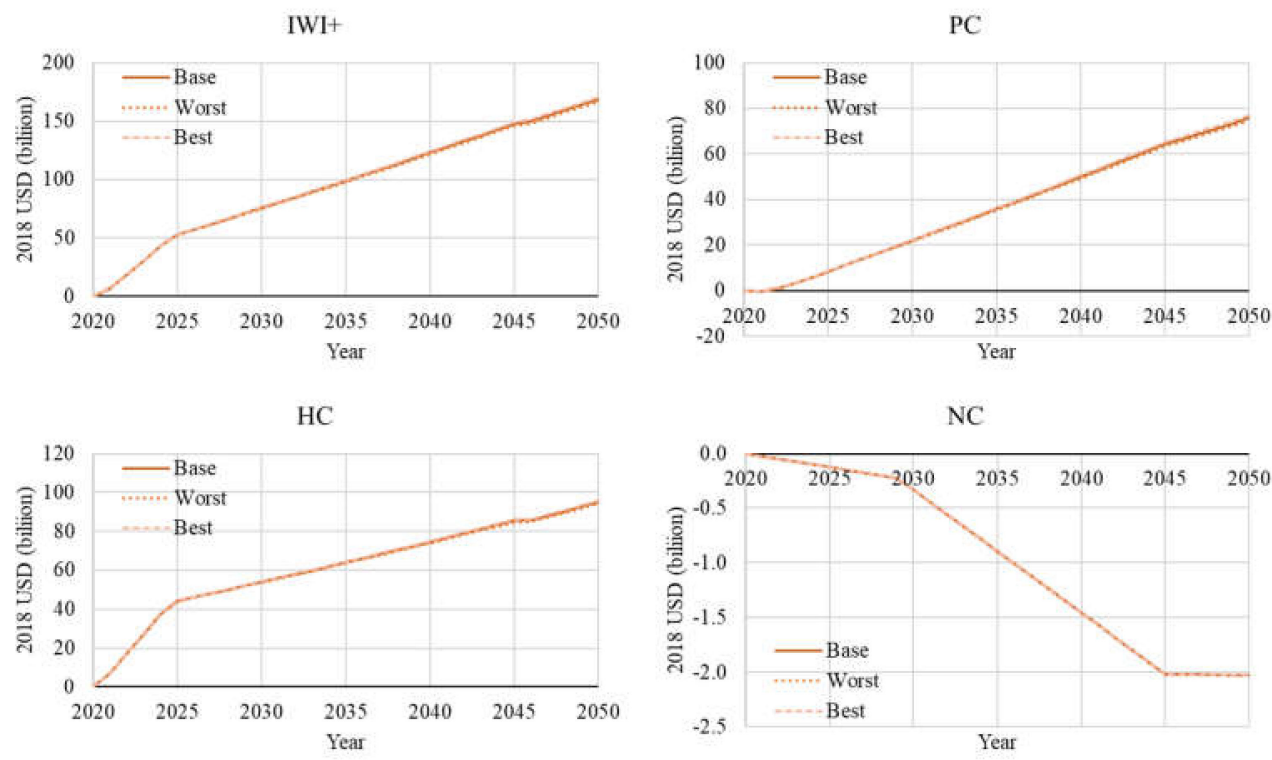

Figure A5. Sensitivity analysis for emissions in Scenario 1 [billion USD]. In the best scenario, emission factors are multiplied by 1.05 in Jakarta and 0.95 in the NCC, respectively. In the worst scenario, the opposed adjustment of the best scenario is done.

\section{References}

1. BBC. Changing Places: Why Countries Decide to Move Their Capitals. Available online: https://www.bbc. com/news/world-49406700 (accessed on 1 October 2019).

2. Gorbiano, M.I.; Tehusijarana, K.M.; Adri, N. Jokowi Picks East Kalimantan. Available online: https://www. thejakartapost.com/multimedia/2019/08/27/jokowi-picks-east-kalimantan.html (accessed on 1 October 2019).

3. BAPPENAS. Dampak Ekonomi dan Skema Pembiayaan Pemindahan Ibu Kota Negara [Economic Impacts and Financing Schemes for Moving Capital of the State Capital]; BAPPENAS (Ministry of National Development Planning of Indonesia): Jakarta, Indonesia, 2019. 
4. BAPPENAS. Rencana Pemindahan Ibu Kota Negara [Planned Relocation of the National Capital]; Indonesia National Minister of Planning and Development: Jakarta, Indonesia, 2019.

5. Andreas, H.; Zainal Abidin, H.; Pradipta, D.; Anggreni Sarsito, D.; Gumilar, I. Insight look the subsidence impact to infrastructures in Jakarta and Semarang area; Key for adaptation and mitigation. In Proceedings of the MATEC Web of Conference, Jakarta, Indonesia, 22 January 2018; Volume 147, pp. 1-8.

6. Ahlenius, H. Extent of Deforestation in Borneo 1950-2005, and Projection towards 2020. Available online: https://www.grida.no/resources/8324 (accessed on 28 October 2019).

7. Ahlenius, H. Orangutan Distribution on Borneo (Indonesia, Malaysia). Available online: https://www.grida. no/resources/8326 (accessed on 28 October 2019).

8. BBC. Will Indonesia's New Capital just Move the Problem to the Jungle? Available online: https://www.bbc. com/news/world-asia-49481090 (accessed on 2 October 2019).

9. Aly, E.A.; Managi, S. Energy infrastructure and their impacts on societies' capital assets: A hybrid simulation approach to inclusive wealth. Energy Policy 2018, 121, 1-12. [CrossRef]

10. Pearson, L.J.; Biggs, R.; Harris, M.; Walker, B. Measuring sustainable development: The promise and difficulties of implementing Inclusive Wealth in the Goulburn-Broken Catchment, Australia. Sustain. Sci. Pract. Policy 2013, 9, 16-27. [CrossRef]

11. Collins, R.D.; Selin, N.E.; De Weck, O.L.; Clark, W.C. Using inclusive wealth for policy evaluation: Application to electricity infrastructure planning in oil-exporting countries. Ecol. Econ. 2017, 133, 23-34. [CrossRef]

12. Akanle, T. UNU, UNEP Launch Inclusive Wealth Index for Measuring Sustainability. Available online: http://sdg.iisd.org/news/unu-unep-launch-inclusive-wealth-index-for-measuring-sustainability/ (accessed on 11 November 2019).

13. UNU-IHDP; UNEP. Inclusive Wealth Report 2012. Measuring Progress toward Sustainability; Cambridge University Press: Cambridge, UK, 2012; ISBN 9781107683396.

14. UNU-IHDP; UNEP. Inclusive Wealth Report 2014. Measuring Progress toward Sustainability; Scherkenbach, C., Tkacikv, J., Eds.; Cambridge University Press: Cambridge, UK, 2014; ISBN 9781107524002.

15. Managi, S.; Kumar, P. Inclusive Wealth Report 2018; Routledge: Oxford, UK, 2018; ISBN 9781138541276.

16. Sterman, J.D. Business Dynamics: Systems Thinking and Modeling for a Complex World; McGraw-Hill Education: New York, NY, USA, 2000; ISBN 978-0072389159.

17. MIT. System Dynamics. Available online: http://web.mit.edu/sysdyn/sd-intro/ (accessed on 16 March 2020).

18. Nguyen, T.; Cook, S.; Ireland, V. Application of System Dynamics to Evaluate the Social and Economic Benefits of Infrastructure Projects. Systems 2017, 5, 29. [CrossRef]

19. UN Population Division. World Population Prospects 2019. Available online: https://population.un.org/wpp/ (accessed on 11 November 2019).

20. FAO. FAOSTAT. Available online: http://www.fao.org/faostat/en/\#data (accessed on 28 October 2019).

21. Muntean, M.; Vignati, E.; Crippa, M.; Solazzo, E.; Schaaf, E.; Guizzardi, D.; Olivier, J.G. Fossil CO 2 Emissions of All World Countries-2018 Report; European Commission: Luxembourg, 2018.

22. Crippa, M.; Guizzardi, D.; Muntean, M.; Schaaf, E.; Dentener, F.; van Aardenne, J.A.; Monni, S.; Doering, U.; Olivier, J.G.J.; Pagliari, V.; et al. Gridded Emissions of Air Pollutants for the Period 1970-2012 within EDGAR v4.3.2. Available online: https://doi.org/10.5194/essd-10-1987-2018 (accessed on 28 October 2019).

23. BPS. Statistics Service Information. Available online: https://silastik.bps.go.id/ (accessed on 6 November 2019).

24. ILO. ILOSTAT. Available online: https://ilostat.ilo.org/ (accessed on 28 October 2019).

25. Lloyd's; Cambridge Centre for Risk Studies at the University of Cambridge Judge Business School. Lloyd's City RIsk Index. Available online: https://cityriskindex.lloyds.com/ (accessed on 18 February 2020).

26. Quistorff, B. Capitalitis? Effects of the 1960 Brazilian Capital Relocation. SSRN Electron. J. 2015, 1-30. [CrossRef]

27. Reva, D. Capital City Relocation and National Security: The Cases of Nigeria and Kazakhstan; University of Pretoria: Pretoria, South Africa, 2016.

28. Moser, S. Putrajaya: Malaysia's new federal administrative capital. Cities 2010, 27, 285-297. [CrossRef]

29. Gordon, D.L.A. Planning Twentieth Century Capital Cities; Taylor \& Francis Ltd.: London, UK, 2006; ISBN 9780415557344.

30. Mubaroq, M.R.; Solikin, A. Review on the Financing Scheme of Indonesia's Capital City Relocation Plan: Lessons Learned from Brazil, Malaysia, and Tanzania. In Proceedings of the Proceedings of the 1st International Conference on Finance Economics and Business, (ICOFEB 2018), Aceh, Indonesia, 12-13 November 2018. 
31. Indonesia Government. Biography of Jakarta. Available online: https://indonesia.go.id/ (accessed on 6 November 2019).

32. IBGE. National Census. Available online: https://www.ibge.gov.br/en/statistics/social/population.html (accessed on 17 January 2020).

33. Bank Indonesia. Foreign Exchange Rates. Available online: https://www.bi.go.id (accessed on 6 November 2019).

34. Williamson, S.H. Seven Ways to Compute the Relative Value of a U.S. Dollar Amount, 1790 to Present. Available online: https://www.measuringworth.com/ (accessed on 6 November 2019).

35. Yusuf, A.A.; Resosudarmo, B.P. Does clean air matter in developing countries' megacities? A hedonic price analysis of the Jakarta housing market, Indonesia. Ecol. Econ. 2009, 68, 1398-1407. [CrossRef]

36. JICA; BAPPENAS. The Study on Integrated Transportation Master Plan for Jabodetabek (Phaseii); Final Report Main Report Volume 2: Pre Feasibility Study; Japan International Cooperation Agency: Tokyo, Japan, 2004; Volume 2.

37. Asri, D.U.; Hidayat, B. Current Transportation Issues in Jakarta and its Impact on Environment. East. Asia Soc. Transp. Stud. 2005, 5, 1792-1798.

38. Syaukat, Y.; Sarma, M.; Falatehan, A.F.; Bahtiar, R. Analysis of Willingness to Pay (WTP) to Determine Road Pricing in Jakarta. Sci. J. PPI-UKM 2014, 1, 258-260.

39. Rioja, F. What Is the Value of Infrastructure Maintenance? A Survey. In Infrastructure and Land Policies; Ingram, G.K., Brandt, K.L., Eds.; Lincoln Institute of Land Policy: Cambridge, MA, USA, 2013; pp. 347-365.

40. Kaming, P.F.; Olomolaiye, P.O.; Holt, G.D.; Harris, F.C. What Motivates Construction Craftsmen in Developing Countries? A Case Study of Indonesia. Build. Environ. 1998, 33, 131-141. [CrossRef]

41. Elmanisa, A.M.; Kartiva, A.A.; Fernando, A.; Arianto, R.; Winarso, H.; Zulkaidi, D. Land Price Mapping of Jabodetabek, Indonesia. Geoplan. J. Geomatics Plan. 2016, 4, 53-62. [CrossRef]

42. Gnagey, M.; Tans, R. Property-Price Determinants in Indonesia. Bull. Indones. Econ. Stud. 2018, 54, 61-84. [CrossRef]

43. Feenstra, R.C.; Inklaar, R.; Timmer, M.P. The Next Generation of the Penn World Table. Am. Econ. Rev. 2015, 105, 3150-3182. [CrossRef]

44. OECD. Household Spending (Indicator). Available online: https://data.oecd.org/hha/household-spending. htm (accessed on 23 December 2019).

45. OECD. Real GDP Long-Term Forecast (Indicator). Available online: https://data.oecd.org/gdp/real-gdp-longterm-forecast.htm\#indicator-chart (accessed on 23 December 2019).

46. Resosudarmo, B.P.; Napitupulu, L. Health and economic impact of air pollution in Jakarta. Econ. Rec. 2004, 80, S65-S75. [CrossRef]

47. UNDP. Briefing note for countries on the 2019 Human Development Report: Indonesia. In Human Development Report 2019: Inequalities in Human Development in the 21st Century; United Nations Development Programme: New York, NY, USA, 2019; pp. 1-9.

48. Klenow, P.J.; Rodríguez-Clare, A. The Neoclassical Revival in Growth Economics: Has It Gone Too Far? Natl. Bur. Econ. Res. 1997, 12, 73-103. [CrossRef]

49. Emberson, L. Air Pollution Impacts on Crops and Forests: An Introduction. In Air Pollution Impacts on Crops and Forests: A Global Assessment; Emberson, L., Ashmore, M., Murray, F., Eds.; Imperial College Press: London, UK, 2003; pp. 3-29.

50. IER. ExternE. Available online: http://www.externe.info/externe_d7/ (accessed on 15 January 2020).

51. Bolt, K.; Matete, M.; Clements, M. Manual for Calculating Adjusted Net Savings; Environment Department, World Bank: Washington, DC, USA, 2002.

52. Van der Ploeg, S.; De Groot, R.S. The TEEB Valuation Database-A Searchable Database of 1310 Estimates of Monetary Values of Ecosystem Services; Foundation for Sustainable Development: Wageningen, The Netherlands, 2010.

53. World Bank. Where is the Wealth of Nations? World Bank: Washington, DC, USA, 2006; ISBN 9780821363546.

54. Cambridge Centre for Risk Studies at the University of Cambridge Judge Business School. Cambridge Global Risk Index for 2018; Cambridge Centre for Risk Studies at the University of Cambridge Judge Business School: Cambridge, UK, 2018.

55. GFDRR. ThinkHazard! Available online: http://thinkhazard.org/ (accessed on 18 February 2020).

56. Fraser, S.; Douglas, J.; Simpson, A.; Kuijper, M.; Winsemius, H.; Burzel, A.; Hohmann, A.; Taillefer, N.; Giraud, P.; ThinkHazard, C. ThinkHazard!: Methodology report Updated for ThinkHazard! Version 2; World Bank Global Facility for Disaster Reduction and Recovery: Washington, DC, USA, 2017. 
57. MAIPARK. Indonesian Earthquake Insurance Statistics 2018; MAIPARK: Jakarta, Indonesia, 2018.

58. JICA. Country Report Indonesia: Natural Disaster Risk Assessment and Area Business Continuity Plan Formulation for Industrial Agglomerated Areas in the ASEAN Region; Japan International Cooperation Agency: Tokyo, Japan, 2004.

59. Roman, P.; Thiry, G. The inclusive wealth index. A critical appraisal. Ecol. Econ. 2016, 124, 185-192. [CrossRef]

60. Page, S.E.; Rieley, J.; Wüst, R.A.J. Lowland tropical peatlands of Southeast Asia. In Peatlands: Evolution and Records of Environmental and Climate Change; Martini, I.P., Cortizas, A.M., Chesworth, W., Eds.; Elsevier Science: Amsterdam, The Netherlands, 2006; pp. 145-172.

(C) 2020 by the authors. Licensee MDPI, Basel, Switzerland. This article is an open access article distributed under the terms and conditions of the Creative Commons Attribution (CC BY) license (http://creativecommons.org/licenses/by/4.0/). 